\title{
Biomass for thermochemical conversion: targets and challenges
}

\author{
Paul Tanger ${ }^{1}$, John L. Field ${ }^{2,3}$, Courtney E. Jahn ${ }^{1}$, Morgan W. DeFoort ${ }^{2}$ and Jan E. Leach ${ }^{1 *}$ \\ ${ }^{1}$ Bioagricultural Sciences and Pest Management, Colorado State University, Fort Collins, CO, USA \\ 2 Engines and Energy Conversion Laboratory, Department of Mechanical Engineering, Colorado State University, Fort Collins, CO, USA \\ ${ }^{3}$ Natural Resource Ecology Laboratory, Colorado State University, Fort Collins, CO, USA
}

\section{Edited by:}

Samuel P. Hazen, University of

Massachusetts, USA

Reviewed by:

Seth DeBolt, University of Kentucky,

USA

Gordon G. Allison, Aberystwyth

University, UK

*Correspondence:

Jan E. Leach, Bioagricultural

Sciences and Pest Management

Colorado State University, 1177

Campus Delivery, Fort Collins,

CO 80523-1177, USA

e-mail: jan.leach@colostate.edu
Bioenergy will be one component of a suite of alternatives to fossil fuels. Effective conversion of biomass to energy will require the careful pairing of advanced conversion technologies with biomass feedstocks optimized for the purpose. Lignocellulosic biomass can be converted to useful energy products via two distinct pathways: enzymatic or thermochemical conversion. The thermochemical pathways are reviewed and potential biotechnology or breeding targets to improve feedstocks for pyrolysis, gasification, and combustion are identified. Biomass traits influencing the effectiveness of the thermochemical process (cell wall composition, mineral and moisture content) differ from those important for enzymatic conversion and so properties are discussed in the language of biologists (biochemical analysis) as well as that of engineers (proximate and ultimate analysis). We discuss the genetic control, potential environmental influence, and consequences of modification of these traits. Improving feedstocks for thermochemical conversion can be accomplished by the optimization of lignin levels, and the reduction of ash and moisture content. We suggest that ultimate analysis and associated properties such as $\mathrm{H}: \mathrm{C}, \mathrm{O}: \mathrm{C}$, and heating value might be more amenable than traditional biochemical analysis to the high-throughput necessary for the phenotyping of large plant populations. Expanding our knowledge of these biomass traits will play a critical role in the utilization of biomass for energy production globally, and add to our understanding of how plants tailor their composition with their environment.

Keywords: biomass composition, thermochemical conversion, high-throughput phenotyping, silica, moisture content, proximate/ultimate analysis, heating value

\section{INTRODUCTION}

\section{MULTIPLE PATHWAYS FROM FEEDSTOCK TO ENERGY}

Our society and economy rely heavily on energy from fossil fuels. Most (84\%) of the world's energy comes from fossil fuels and demand will increase as world energy consumption is expected to increase 53\% by 2035 (EIA, 2011). As prices rise, unconventional fossil resources (tar sand oil, shale gas, arctic and deepwater oil) may become economically viable to extract, but they are ultimately a limited resource and carry risks to our health and environment (Kelly et al., 2010; Osborn et al., 2011; Frohlich, 2012).

Bioenergy, derived from plants that use sunlight and $\mathrm{CO}_{2}$ to assimilate carbon into biomass, has emerged as a potentially sustainable energy source with low climate impact. The Renewable Fuel Standard, enacted in 2005 and expanded in 2007, mandates liquid biofuel production in the US (EISA, 2007). The majority of the fuel produced today to support this mandate is derived from either ethanol fermented from corn grain, or biodiesel from soybean oil, but by the year 2022, 58\% of the legislated 36 billion gallons is required to be produced from cellulosic or advanced cellulosic biomass. Technological advances and commercialization have not occurred as quickly as expected, and several barriers must be overcome to achieve these targets (National Research Council, 2011).

One of these barriers is the production of high quality biomass that can be economically converted into useful energy products. Biomass quality depends on the plant composition-cellulosic biomass is primarily comprised of cellulose, hemicellulose, lignin, and lesser amounts of other extractable components such as pectins, proteins, etc. that make up the plant cell wall. Cellulose is a polymer of D-glucose. Hemicellulose is a general term for heterogeneous branched five and six carbon sugars. Lignin is a complex branched polymer of phenolics, and is classified as three major types, based on the monomers present: sinapyl (S) coumaryl (H) and coniferyl (G) (Albersheim et al., 2010). The proportions and specific chemical composition of these components varies greatly among species (Pauly and Keegstra, 2008; Carroll and Somerville, 2009; Allison et al., 2010; Tao et al., 2012b; Zhao et al., 2012a). Furthermore, significant compositional variation has been observed within a species (Jin and Chen, 2006; Tao et al., 2012b), within tissue type (Summers et al., 2003; Monti et al., 2008; Rancour et al., 2012; Sabatier et al., 2012), as well as between developmental stages (Rancour et al., 2012), cell types, and even regions of the cell wall (Albersheim et al., 2010). 
Additional variability is observed throughout the growing season and as plants senesce (Landström et al., 1996; Adler et al., 2006; Hodgson et al., 2010; Nassi o Di Nasso et al., 2010; Singh et al., 2012; Zhao et al., 2012b), as well as across different environments (Adler et al., 2006; Mann et al., 2009; Allison et al., 2011; Monono et al., 2013; Serapiglia et al., 2013).

Variation, either naturally existing variation or driven with biotechnology, is the ultimate source of improved crop varieties. Most feedstock improvement efforts have focused on the enzymatic conversion pathway, and how to increase the availability of components of plant biomass that can readily be converted into simple sugars and fermented into alcohols; i.e., maximizing cellulose and minimizing lignin. Other articles in this research topic address challenges and advances in enzymatic conversion, as have multiple recent reviews (Vermerris, 2011; Feltus and Vandenbrink, 2012; Jordan et al., 2012; Nookaraju et al., 2013).

A promising alternative form of bioenergy production is via thermochemical conversion-the controlled heating or oxidation of biomass (Demirbas, 2004; Goyal et al., 2008). The term covers a range of technologies including pyrolysis, gasification, and combustion which can be configured to produce outputs of heat, electricity, or gaseous or liquid precursors for upgrading to liquid fuels or chemical feedstocks (Figure 1 and Butler et al., 2011; Wang et al., 2011; Brar et al., 2012; Bridgwater, 2012; Solantausta et al., 2012). Thermochemical technologies show great promise for the production of renewable electricity, both in the context of biomass co-firing in existing coal powerplants (Demirbaş, 2003b; Baxter, 2005), and for decentralized electrification projects in developing countries (Yin et al., 2002; Hiloidhari and Baruah, 2011; Shackley et al., 2012). Thermochemical produced electricity could help fulfill standards enacted in many US states that require a certain percentage of electricity be produced from renewable sources (Carley, 2009; DOE DSIRE, 2012; EIA, 2012). In some cases, thermochemical production of renewable electricity or liquid fuels and associated co-products is the most effective use of biomass for fossil energy displacement (Botha and von Blottnitz, 2006; Campbell et al., 2009; Cherubini et al., 2009; Searcy and Flynn, 2010; Giuntoli et al., 2012).

A well-functioning system requires the pairing of appropriate feedstocks and conversion technologies (Robbins et al., 2012), but optimization of biomass for thermochemical conversion has received little attention. The paradigm within which plant biologists discuss and analyze biomass is different than that of engineers analyzing feedstocks for thermochemical systems. While there is overlap between the paradigms, thermochemical feedstock development could focus on traits or approaches that provide the most direct path to optimized feedstock composition. In this review, we discuss how, through collaboration of biologists and engineers, optimized biomass composition and process engineering might result in reduced transport and pre-processing costs and maximized energy yields via thermochemical utilization of biomass.

We begin with a review of thermochemical conversion technologies with an emphasis on the feedstock properties that are important for each technology and relate these properties back to biomass traits that are commonly measured by biologists.

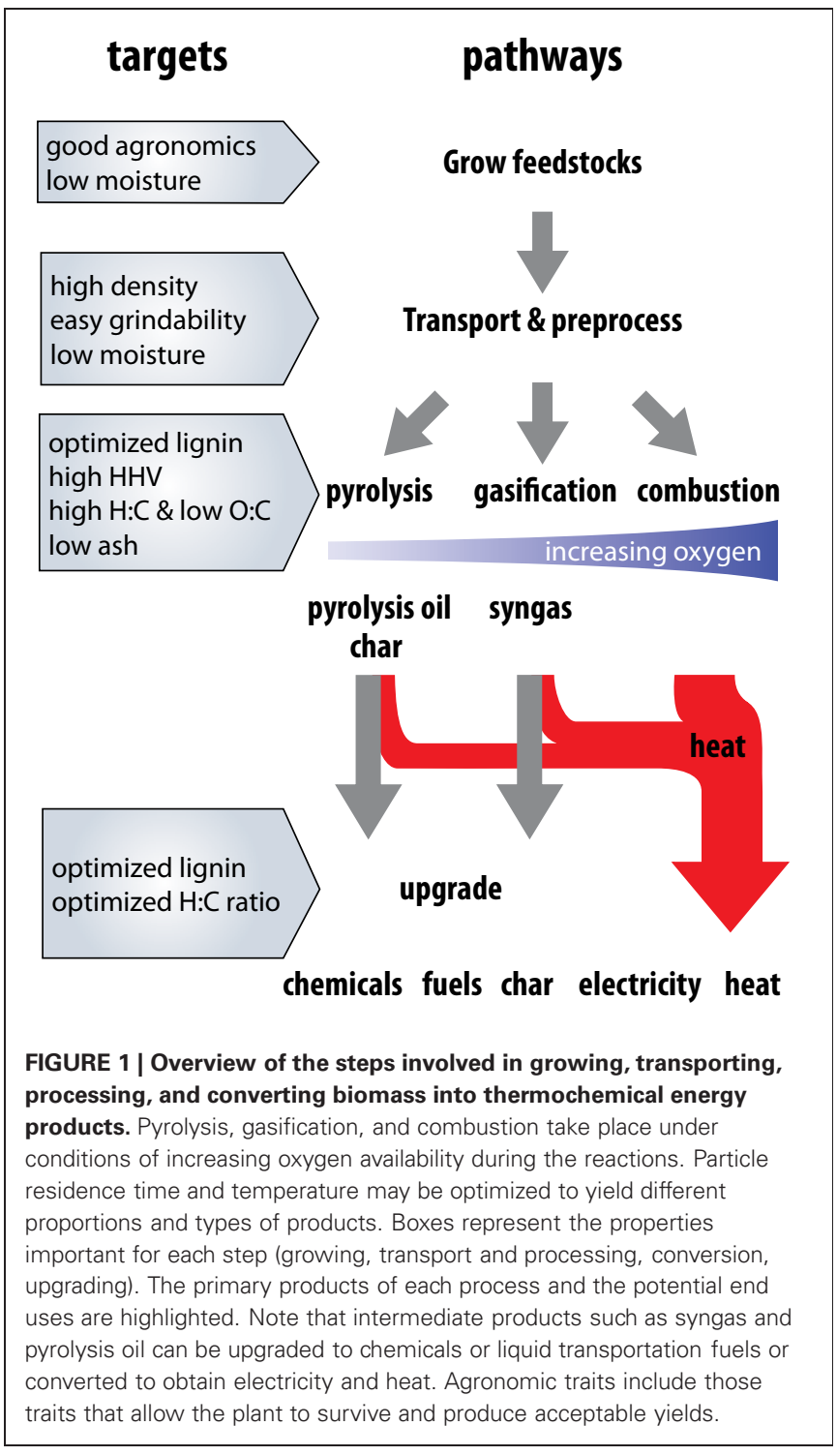

This is followed by a discussion of the natural variation in plant traits that can be exploited for optimization of these properties, including what is known of the genetics governing those traits, and the potential impacts of modifying these traits at a systems level. We end with a discussion of how best to measure these properties and traits, and offer a perspective on which approaches might be useful for high-throughput phenotyping. To help relate the different biomass traits that biologists and engineers measure, we provide a brief list of terms and definitions (Table 1). Areas where there are large gaps in knowledge are highlighted as future research needs. Our focus is on cellulosic biomass from herbaceous crops because (1) herbaceous agricultural residues comprise a large potential resource (DOE, 2011), (2) a large fraction of the US biofuel mandate is expected to be dedicated herbaceous bioenergy crops (DOE, 2009; USDA, 2010), and (3) herbaceous crops can be grown in more regions than woody crops, and allow more flexibility in year to year land allocation. 


\section{Table 1 | Common terms used in this review in the context of biomass for bioenergy.}

\begin{tabular}{|c|c|}
\hline $\begin{array}{l}\text { Biochemical } \\
\text { analysis }\end{array}$ & $\begin{array}{l}\text { Characterization of biomass in terms of structural } \\
\text { and non-structural carbohydrates, lignin, protein, and } \\
\text { extractives (pectins, lipids, etc.) }\end{array}$ \\
\hline $\begin{array}{l}\text { Enzymatic } \\
\text { conversion }\end{array}$ & $\begin{array}{l}\text { Use of microorganisms or pure enzymes to transform } \\
\text { feedstocks into energy products and co-products, e.g., } \\
\text { fermentation, anaerobic digestion }\end{array}$ \\
\hline Fixed carbon (FC) & $\begin{array}{l}\text { Mass remaining as a solid after proximate analysis, } \\
\text { excluding ash }\end{array}$ \\
\hline $\begin{array}{l}\text { Higher heating } \\
\text { value }(\mathrm{HHV})\end{array}$ & $\begin{array}{l}\text { Energy released as biomass undergoes complete com- } \\
\text { bustion to } \mathrm{CO}_{2}, \mathrm{H}_{2} \mathrm{O} \text { (condensed), and other minor } \\
\text { products at standardized conditions }\end{array}$ \\
\hline $\begin{array}{l}\text { Intensive } \\
\text { properties }\end{array}$ & $\begin{array}{l}\text { Non-separable traits that are independent of the mass } \\
\text { of a sample }\end{array}$ \\
\hline Property & $\begin{array}{l}\text { Trait or parameter in the context of a certain bioenergy } \\
\text { conversion pathway or engineering systems }\end{array}$ \\
\hline Phenotype & $\begin{array}{l}\text { Observable or measurable characteristic specific to a } \\
\text { given environment }\end{array}$ \\
\hline $\begin{array}{l}\text { Proximate } \\
\text { analysis }\end{array}$ & $\begin{array}{l}\text { Characterization in terms of the mass volatilized (as } \\
\text { moisture and volatile matter) and mass remaining (fixed } \\
\text { carbon and ash) during a standardized heating regime }\end{array}$ \\
\hline $\begin{array}{l}\text { Summative } \\
\text { properties }\end{array}$ & $\begin{array}{l}\text { Traits that describe specific separable components of } \\
\text { the biomass and sum to } 100 \% \text { in the context of a mass } \\
\text { balance }\end{array}$ \\
\hline $\begin{array}{l}\text { Thermochemical } \\
\text { conversion }\end{array}$ & $\begin{array}{l}\text { Controlled heating or oxidation of feedstocks to pro- } \\
\text { duce energy products and/or heat, e.g., pyrolysis, } \\
\text { gasification, combustion }\end{array}$ \\
\hline Trait & $\begin{array}{l}\text { Genetic or physical characteristics (physical character- } \\
\text { istics are also referred to as phenotypes) }\end{array}$ \\
\hline Ultimate analysis & $\begin{array}{l}\text { Characterization of biomass in terms of its individual } \\
\text { constituent elements }(\mathrm{C}, \mathrm{H}, \mathrm{O}, \mathrm{N}, \mathrm{S} \text {, etc.) }\end{array}$ \\
\hline $\begin{array}{l}\text { Volatile matter } \\
\text { (VM) }\end{array}$ & $\begin{array}{l}\text { Mass loss as gaseous products (excluding moisture) } \\
\text { during proximate analysis }\end{array}$ \\
\hline
\end{tabular}

\section{FEEDSTOCK PROPERTIES FOR THERMOCHEMICAL CONVERSION \\ THERMOCHEMICAL CONVERSION TECHNOLOGIES}

Thermochemical conversion is the controlled heating and/or oxidation of biomass as part of several pathways to produce intermediate energy carriers or heat (Figure 1). Included is everything from biomass combustion, one of the simplest and earliest examples of human energy use, to experimental technologies for the production of liquid transportation fuels and chemical feedstocks. Thermochemical conversion technologies are classified by their associated oxidation environment, particle size and heating rate, ranging from heating biomass in an oxygenfree environment (endothermic) to full exothermic oxidation of biomass.

Pyrolysis is the thermal decomposition of biomass into highly heterogeneous gaseous, liquid, and solid intermediates in the absence of oxygen; the process is endothermic. The liquid product (pyrolysis oil) is a heterogeneous mixture characterized by high oxygen content and alkalinity, which can be upgraded to fuels or chemicals. The solid product (char) can be used as a fuel or soil amendment (Field et al., 2013). Pyrolysis is differentiated between slow pyrolysis, with residence times ranging from minutes to days and optimized for the production of char whereas fast pyrolysis, with residence times on the order of seconds to minutes, is optimized for the production of pyrolysis oil (Babu, 2008). On the engineering front, research is focused on optimizing process variables (temperature, heating rate, oxidation environment) and product upgrading via catalytic and thermal processes to produce infrastructure-compatible liquid transportation fuels (Demirbas, 2007).

Gasification is the exothermic partial oxidation of biomass with process conditions optimized for high yields of gaseous products (syngas or producer gas) rich in $\mathrm{CO}, \mathrm{H}_{2}, \mathrm{CH}_{4}$, and $\mathrm{CO}_{2}$. The gas can be cleaned and used directly as an engine fuel or upgraded to liquid fuels or chemical feedstocks through biological fermentation (Datar et al., 2004) or catalytic upgrading via the Fischer-Tropsch process (Boerrigter and Rauch, 2005; Huber et al., 2006; Wang et al., 2008). One of the challenges of gasification is the management of higher molecular weight volatiles that condense into tars; these tars are both a fouling challenge and a potential source of persistent environmental pollutants such as polycyclic aromatic hydrocarbons (Milne et al., 1998).

The direct combustion of biomass is still the dominant bioenergy pathway worldwide (Gaul, 2012). Complete combustion involves the production of heat as a result of the oxidation of carbon- and hydrogen-rich biomass to $\mathrm{CO}_{2}$ and $\mathrm{H}_{2} \mathrm{O}$. However, the detailed chemical kinetics of the reactions that take place during biomass combustion are complex (Jenkins et al., 1998; Babu, 2008) and imperfect combustion results in the release of intermediates including environmental air pollutants such as $\mathrm{CH}_{4}, \mathrm{CO}$, and particulate matter (PM). Additionally, fuel impurities, such as sulfur and nitrogen, are associated with emission of $\mathrm{SO}_{\mathrm{X}}$ and $\mathrm{NO}_{\mathrm{X}}$ (Robbins et al., 2012).

Other thermochemical technologies include carbonization, the production of charcoal via the partial oxidation of woody feedstocks with long residence time (Bailis, 2009), and hydrothermal approaches, which utilize an aqueous environment at moderate temperatures $\left(200-600^{\circ} \mathrm{C}\right)$ and high pressures $(5-40 \mathrm{MPa})$ to decompose biomass into solid, liquid, and gaseous intermediates (Peterson et al., 2008; Brown, 2011). Another technology, torrefaction, is the low temperature $\left(200-300^{\circ} \mathrm{C}\right)$ pyrolysis of biomass in order to remove water and volatiles, increasing its energy density and susceptibility to mechanical pretreatment (Van der Stelt et al., 2011). The remainder of this review will focus on pyrolysis, gasification, and combustion, as these are the most fully developed modern bioenergy pathways with the most clearly defined feedstock requirements.

\section{RELATIONSHIPS BETWEEN FEEDSTOCK PROPERTIES}

The performance of these thermochemical conversion pathways relies on the use of appropriate biomass feedstocks. The mass balance of a kilogram of biomass is commonly conceptualized in three different ways, via either biochemical, proximate, or ultimate analysis (Figure 2A). Biochemical analysis refers to the relative abundance of various biopolymers (e.g., cellulose, lignin, etc) in the biomass, whereas ultimate analysis refers to the relative 
abundance of individual elements (e.g., C, H, O, N, and S). Proximate analysis involves the heating of biomass to quantify its thermal recalcitrance via the relative proportions of fixed carbon (FC) and volatile matter (VM), a method originally designed for the characterization of coal (e.g., American Society for Testing and Materials, ASTM standard D3172). These different conceptualizations are alternate ways to describe the same biomass; for example, a higher lignin:cellulose ratio (biochemical) also implies lower $\mathrm{H}: \mathrm{C}$ and O:C ratios (ultimate) (Couhert et al., 2009). Moisture and elemental ash complete the mass balance of a unit of freshly-harvested biomass, and are universal across these different conceptualizations. Different combinations of these mass-based properties (summative properties) result in different bulk properties (intensive properties) such as grindability (comminution), density and heating value.

Feedstock properties that affect thermochemical conversion effectiveness include heating value, ash content, moisture level, and others discussed next. While thermochemical conversion engineers typically describe biomass in terms of proximate or ultimate analysis, biologists and breeders are more accustomed to the terminology of biochemical analysis. Thus, important properties are introduced in the context of proximate/ultimate analysis, and then related back to their biochemical equivalents. Current knowledge of the genetic and environmental control of these biochemical properties are then described in detail in the section titled "Genetic Control of Traits Related to Feedstock Properties."

\section{HEATING VALUE AND RATIOS OF C, H, AND 0}

Heating value, also known as calorific value, is the energy available in the feedstock as estimated from the heat released during complete combustion to $\mathrm{CO}_{2}, \mathrm{H}_{2} \mathrm{O}$ (gaseous $\mathrm{H}_{2} \mathrm{O}$ for lower heating value, $\mathrm{LHV}$, or liquid $\mathrm{H}_{2} \mathrm{O}$ for higher heating value, $\mathrm{HHV}$ ), and other minor products $\left(\mathrm{N}_{2}\right.$, ash, etc.), and is a primary measure of quality of a feedstock. Moisture content impacts the useful energy of freshly harvested biomass as heat liberated during combustion is wasted evaporating this moisture (Bridgwater et al., 2002). Since HHV is a mass based measurement, high mineral content leads to a decrease in HHV, because minerals contribute little energy during biomass oxidation (Jenkins et al., 1996; Sheng and Azevedo, 2005). This is particularly important for grasses and other herbaceous feedstocks that can consist of up to $27 \%$ ash by mass (Table 2).

Biomass feedstocks are also described in terms of ultimate analysis based on the relative content of individual elements such as $\mathrm{C}, \mathrm{H}$, and $\mathrm{O}$. The overall ratios of these elements are directly related to the biochemical components of the cell wall. Cellulose has a higher H:C and O:C ratio than lignin (Couhert et al., 2009). Lignin has a higher HHV than cellulose or starch (Helsel and Wedin, 1981; Demirbaş, 2001), consistent with the idea that oxygenated fuels release less heat on combustion (Vermerris and Saballos, 2013). This is an example of divergent feedstock requirements for enzymatic vs. thermochemical conversion pathways: while minimizing lignin improves hydrolysis and fermentation yields, high lignin is beneficial for the energy balance of thermochemical systems.

Upgrading gaseous pyrolysis and gasification products to liquid fuels also requires a specific $\mathrm{H}$ :C stoichiometry (Datar et al.,
2004; Wright and Brown, 2007). Biomass has a low H:C ratio (ranging from 0.7 to 2.8 in Table 2) relative to that of the desired liquid products (2-4 for alcohols and alkanes), so full conversion requires adding supplemental hydrogen in the form of steam or $\mathrm{H}_{2}$, or removing carbon as $\mathrm{CO}_{2}$ (Borgwardt, 1999; Pereira et al., 2012). High lignin levels may be advantageous for thermochemical conversion pathways targeting liquid fuels, as it may move the process closer to overall stoichiometric balance.

\section{PROXIMATE ANALYSIS AND CONVERSION PRODUCT YIELDS}

Proximate analysis separates the biomass into four categories of importance to thermal conversion: moisture, VM (gases and vapors driven off during pyrolysis), FC (non-volatile carbon), and ash (inorganic residue remaining after combustion) (Miles et al., 1996; Jenkins et al., 1998; Riley, 2007). The measurement is a proxy for thermochemical conversion performance, and the relative proportions of FC vs. VM are related to the relative yields and composition of solid, liquid, and gaseous products generated during pyrolysis and gasification (Brar et al., 2012). Even for combustion, the FC:VM ratio may significantly change the emissions profile of products of incomplete combustion (Cummer and Brown, 2002). Biomass generally contains high levels of VM (ranging from 64 to $98 \%$, Table 2) compared to fossil coal [typically below 40\% (Vassilev et al., 2010)].

In addition to impact on heating value, the relative concentrations of cellulose and lignin also affect the yields of thermochemical conversion products. The different biochemical constituents of biomass have different levels of thermal stability, and as pyrolysis temperatures increase hemicellulose reacts first, followed by cellulose and then lignin (Fahmi et al., 2007; Gani and Naruse, 2007). This is consistent with studies that show isolated lignin extracts having a higher FC content than pure cellulose (Couhert et al., 2009), a strong positive correlation between FC and lignin across multiple biomass samples (Demirbaş, 2003a), and increasing lignin levels associated with low gas yields and high char yields during fast pyrolysis (Lv et al., 2010). However, several studies suggest the opposite, showing cases where increasing lignin is associated with lower FC (Fahmi et al., 2007, 2008), or increasing yields of pyrolysis oils (Tröger et al., 2013).

Clear relationships between FC:VM and lignin:cellulose content in biomass samples are likely confounded by the presence of minerals, some of which exert a strong influence on the yields and qualities of thermochemical conversion products due to catalytic activity (Couhert et al., 2009; Lv et al., 2010). For pyrolysis, high mineral content reduces oil yield and increases char and gas products (Fahmi et al., 2007; Couhert et al., 2009; Tröger et al., 2013). Relationships between VM and lignin are confounded by ash content (Raveendran et al., 1995). In addition, ash exerts a catalytic effect on the liquid fraction, encouraging cracking of high molecular weight species into lighter ones (Fahmi et al., 2008). The catalytic activity of ash changes the dynamics of combustion and gasification; reducing the ash content of biomass by washing has been shown to increase the temperature of peak combustion rate (Fahmi et al., 2007) but decrease the temperature of peak gasification mass loss rate ( $\mathrm{Lv}$ et al., 2010). Many studies show a negative correlation between mineral content and lignin across many types of biomass (Fahmi et al., 2007, 2008; Lv et al., 


\section{A}

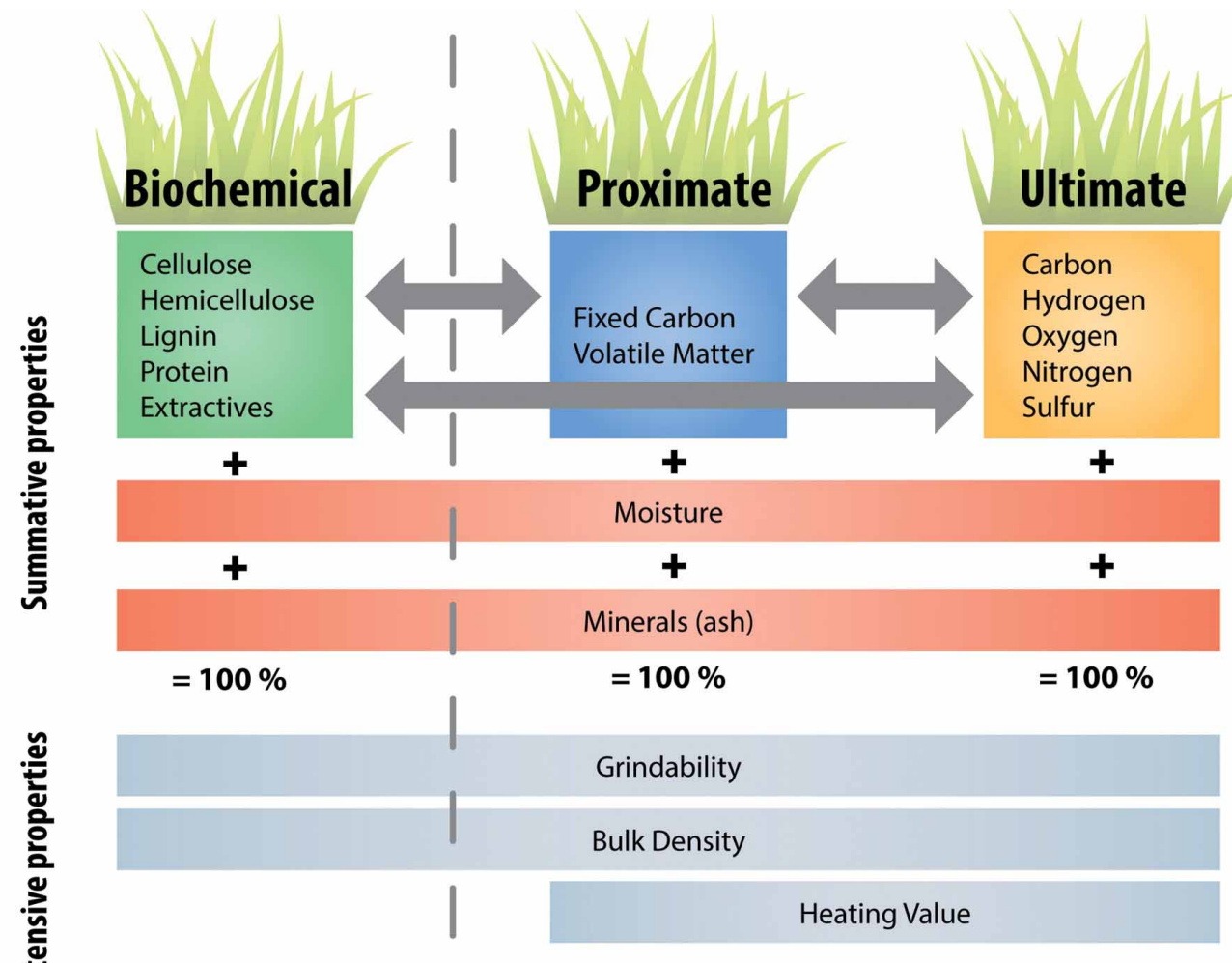

Enzymatic

Thermochemical

\begin{tabular}{|c|c|c|c|}
\hline \multirow[t]{18}{*}{$\mathbf{B}$} & property & primary methods & ASTM standards \\
\hline & Biochemical & & E1821, E1758 \\
\hline & Cellulose & quantititve saccharification, detergent fiber, TGA & D5896 \\
\hline & Hemicellulose & quantititve saccharification, detergent fiber, TGA & D5896 \\
\hline & Lignin & detergent fiber, Klason lignin, others (see text) & D1106, D1721 \\
\hline & Protein & quantification of $\mathrm{N}$ content with a conversion factor & \\
\hline & Proximate & & D3172, D7582 \\
\hline & $\begin{array}{l}\text { Fixed Carbon (FC) } \\
\text { Volatile Matter (VM) }\end{array}$ & mass loss after heating (VM), by subtraction (FC) & $\mathrm{E} 872$ \\
\hline & Ultimate & & D3176 \\
\hline & $\mathrm{C}, \mathrm{H}, \mathrm{O}$ & GC of combustion products ( $O$ by subtraction) & E777 \\
\hline & $\mathrm{N}$ & acid digestion to ammonia salts, GC of combustion products & E778 \\
\hline & $\mathrm{S}$ & precipitation of ash, GC of combustion products & E775 \\
\hline & Moisture & mass loss after oven drying & E871 \\
\hline & Total ash & mass remaining after complete combustion & E1755 \\
\hline & Elemental ash & atomic absorption spectroscopy (AAS), ICP-OES, ICP-MS & D3682 \\
\hline & Grindability & energy consumption of grinding equipment & D409 \\
\hline & Bulk Density & mass per volume of sample ground to certain size & $\mathrm{E} 873$ \\
\hline & Heating Value & bomb calorimetry & D5865 \\
\hline
\end{tabular}

FIGURE 2 | Overview of the relationships between biomass traits and properties, and common methods of quantification. Colors for each property are maintained throughout Figure 2. (A) Biomass

characterization in terms of summative properties (shown in green, blue, orange, and red) and intensive properties (shown in gray). Three common paradigms for describing biomass are inter-related: biochemical, proximate, and ultimate. While enzymatic conversion has focused on characterizing biomass in a biochemical paradigm, two alternatives more appropriate for thermochemical conversion are proximate and ultimate analysis. Moisture and minerals (ash) are common across all paradigms. (B) Examples of common primary (direct) methods of quantifying each component identified in (A). Note that this list is not complete, and note that proximate analysis necessitates moisture and total ash quantification. Elements that remain in the ash when biomass is combusted are referred to as minerals before combustion and ash afterwards. Examples of relevant ASTM standards for biomass, wood, refuse, or coal are listed. These direct methods are contrasted with indirect methods described in the text but not shown here. 
Table 2 | Ranges of key thermochemical properties in several biomass feedstocks as summarized from literature*

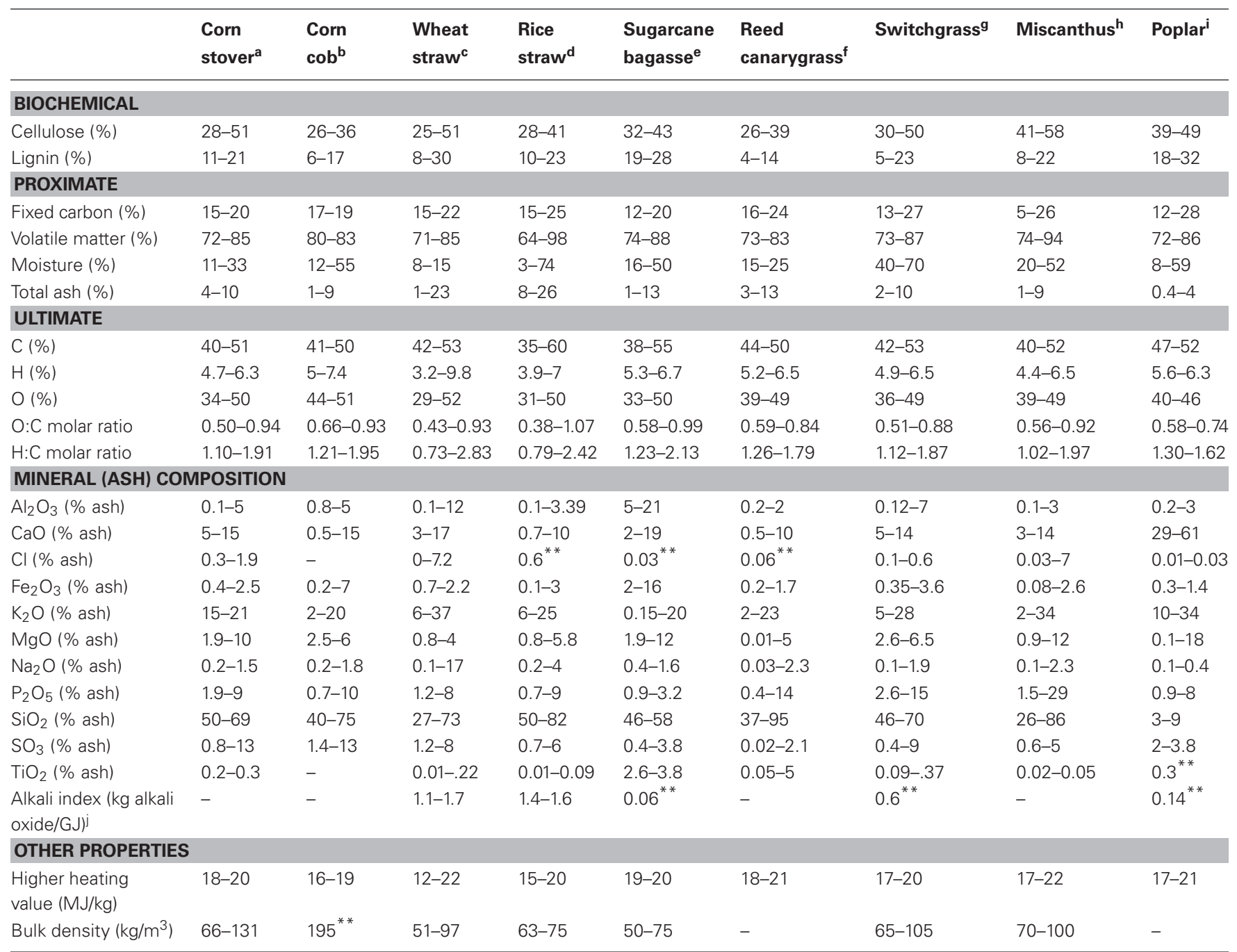

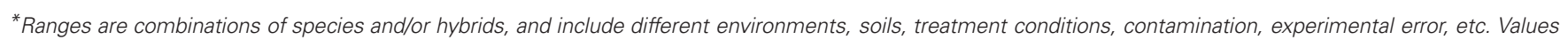

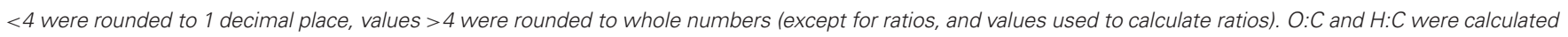

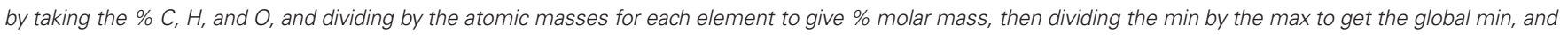

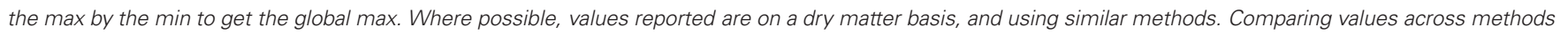

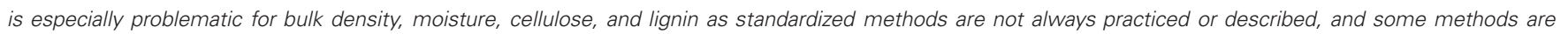
more accurate than others.

** Only individual values were found in the literature review.

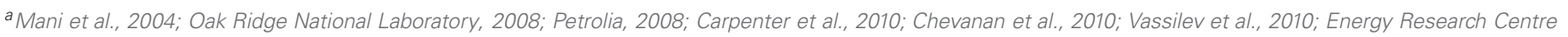
of the Netherlands, 2012; Tao et al., 2012a,b; Zhao et al., 2012a.

bS ${ }^{b}$ ith et al., 1985; Coovattanachai, 1989; Spokas, 2010; Energy Research Centre of the Netherlands, 2012; Tao et al., 2012a,b; Zhao et al., 2012a.

c Jenkins et al., 1998; McKendry, 2002a; Mani et al., 2004; Lam et al., 2008; Carroll and Somerville, 2009; Wu et al., 2009; Carpenter et al., 2010; Chevanan et al., 2010; Spokas, 2010; Energy Research Centre of the Netherlands, 2012; Tao et al., 2012a,b.

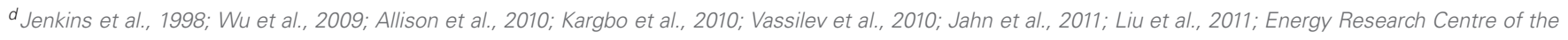
Netherlands, 2012; Tao et al., 2012a,b; Zhang et al., 2012; Zhao et al., 2012a.

e Jenkins et al., 1998; Kaar et al., 1998; Tsai et al., 2006; Spokas, 2010; Vassilev et al., 2010; Energy Research Centre of the Netherlands, 2012; Tao et al., 2012a,b.

${ }^{f}$ Fahmi et al., 2008; Lindh et al., 2009; Allison et al., 2010; Vassilev et al., 2010; Energy Research Centre of the Netherlands, 2012; Tao et al., 2012a,b.

g Jenkins et al., 1998; McKendry, 2002a; Mani et al., 2004; Lam et al., 2008; Sokhansanj et al., 2009; Carpenter et al., 2010; Chevanan et al., 2010; Tao et al., 2012a.

${ }^{\text {h} C l i f t o n-B r o w n}$ and Lewandowski, 2002; Allison et al., 2010; Arabhosseini et al., 2010; Energy Research Centre of the Netherlands, 2012; Tao et al., 2012a,b.

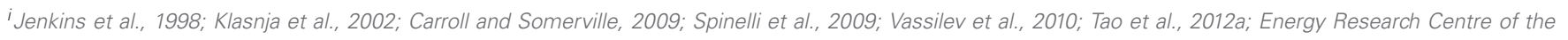
Netherlands, 2012; Tao et al., 2012b; Zhao et al., 2012a.

${ }^{j}$ Alkali index is a ratio calculated from the relative amounts of $\mathrm{K}_{2} \mathrm{O}$ and $\mathrm{Na}_{2} \mathrm{O}$. See text or Jenkins et al. (1998) for detailed explanation. 
2010). Thus, the relationship between ash, lignin, and pyrolysis product yield is complex and careful experimental manipulation will be necessary to determine the causality underlying the observed correlations of low ash, high lignin, and high yields of heavy liquid products (Fahmi et al., 2008; Couhert et al., 2009).

\section{OTHER EFFECTS OF MINERAL CONTENT}

Besides lowering the heating value of biomass and changing the distribution of conversion products, mineral and elemental ions that plants accumulate can interfere with the operation of thermochemical conversion equipment. The elements in plant biomass volatilize during combustion and form a liquid slag or solid deposits as they cool (Miles et al., 1996). The elements $\mathrm{Na}, \mathrm{K}, \mathrm{Mg}, \mathrm{Ca}$ as well as $\mathrm{Cl}, \mathrm{S}$ and $\mathrm{Si}$ are the most problematic for thermochemical processes (Miles et al., 1996), and the combination of alkali metals with silica can form alkali silicates (McKendry, 2002b)—see Box 1 for more information regarding silica. The $\mathrm{Cl}$ in biomass can also be a significant problem because it interacts with vaporized metals, shuttling them to boiler surfaces where they form sulfates (Allison et al., 2010). Cl can also lead to elevated $\mathrm{HCl}$ and dioxin emissions (Lewandowski and Kicherer, 1997). As volatile gases combine, they form corrosive deposits that degrade components of the boiler. Other interactions can occur between the elements in biomass and coal when co-fired (Dayton et al., 1999). Since gasification can occur at lower temperatures, the severity of these issues might be reduced with that process; however, other issues can become more severe [Mansaray et al., 1999 and see Lv et al. (2010) for discussion]. Although difficult to generalize due to the complex and unique interactions that occur in each feedstock, ash content above $5 \%$ is probably unacceptable (McKendry, 2002c) and element specific recommendations are listed elsewhere (Van Loo and Koppejan, 2008). The alkali index $\left(\mathrm{kg} \mathrm{K}_{2} \mathrm{O}\right.$ and $\mathrm{Na}_{2} \mathrm{O}$ per GJ energy) can be used to predict performance in a thermochemical setting (Jenkins et al., 1998). With an alkali index above $0.17 \mathrm{~kg} / \mathrm{GJ}$, fouling is probable, and above $0.34 \mathrm{~kg} / \mathrm{GJ}$, it is almost certain. Several other indices exist, but were created for coal, so may not be good predictors for biomass (Yin et al., 2008). High feedstock mineral content can be mitigated to a certain extent by using newer alloys to construct components that can minimize and withstand some corrosion, and controlling the temperature of the reaction (Jenkins et al., 1998; Fahmi et al., 2008).

\section{MOISTURE CONTENT}

Moisture content is a measure of the amount of water in biomass and is usually expressed as percent mass (wet basis). In addition to reducing the net heating value as discussed previously, high moisture content can reduce the effectiveness of individual thermochemical conversion processes. For combustion or co-firing, low moisture content, preferably around $5 \%$, is desired because incomplete combustion can occur when the moisture content is too high. Some systems such as fluidized bed combustors are more flexible, and allow up to 35\% moisture (Bridgwater et al., 2002). For gasification, acceptable moisture content can be as high as $20 \%$ or $30 \%$ (Cummer and Brown, 2002), but more commonly is around 15\% moisture. For pyrolysis, initial moisture content contributes to the water content in the pyrolysis oil and above around $10 \%$ moisture, the oil produced will separate into two phases (Brar et al., 2012; Solantausta et al., 2012). For hydrothermal conversion, wet biomass can be used without drying, but these technologies are still in the development stages (Yoshida et al., 2004; Waldner and Vogel, 2005; Peterson et al., 2008; Pereira et al., 2012).

\section{OTHER CONSIDERATIONS}

In general, biomass has low amounts of $\mathrm{S}$ relative to fossil fuels, which minimizes $\mathrm{SO}_{\mathrm{X}}$ pollution from gasification or combustion systems and avoids catalyst poisoning in fast pyrolysis systems (Brown, 2011). It can have similar or higher $\mathrm{N}$, which contributes to $\mathrm{NO}_{\mathrm{X}}$ emissions, but this can be mitigated to some extent through engineering in the process, e.g., by the use of exhaust scrubbers (Yin et al., 2008). High levels of nitrogen can also be problematic for the quality of liquid fuel products from fast pyrolysis (Wilson et al., 2013). For combustion processes, lignin is associated with PM emissions (Williams et al., 2012), a factor that must be balanced against the associated increase in feedstock HHV from a systems perspective.

In addition to direct effects on thermochemical conversion performance, biomass properties are also relevant to the upstream logistics associated with biomass transport and mechanical pretreatment. Minimizing moisture reduces weight during transport from the field, and maximizing dry bulk density allows more cost effective transport of biomass. It has been estimated that reducing moisture content from 45 to $35 \%$ in biomass can lead to a $25 \%$ increase in the net present value of a thermochemical project producing ethanol from cellulosic biomass - mostly by reducing the energy and cost of drying the biomass (Gonzalez et al., 2012). Grindability relates to many other properties including moisture content and composition (Ghorbani et al., 2010). Beyond impacts on biomass transport costs, bulk density can influence how easily biomass can be ground for processing (Cabiles et al., 2008).

\section{GENETIC CONTROL OF TRAITS RELATED TO FEEDSTOCK PROPERTIES}

As highlighted in Figure 2A and introduced in the previous section, feedstock properties are related to biochemical traits that have been the focus of research by the forage, pulp and paper industry, as well as enzymatic bioenergy research for many years. These biochemical traits are more easily explained in the context of genes that encode the proteins that synthesize and deliver the components of the cell wall as well as the enzymes responsible for assembly of the wall components into complex structures.

For breeding or biotechnology approaches to improve cell wall composition, a major constraint is understanding which genes or gene pathways are important. Relating genotype to phenotype, i.e., to assign a gene responsible for a particular phenotype, allows identification, functional analysis, and modification of the gene (or its regulation) to improve the phenotype. For example, experiments that modify genes individually and in combination show the effect of a given gene on the composition of the 


\section{Box 1 | Silica in Grasses: Example and Opportunity.}

We present silica here as a practical matter-in grasses it can represent a large proportion of ash content-and as an example of how existing genetic knowledge might be leveraged to optimize a thermochemical trait in feedstocks. Silica does not provide energy during thermochemical conversion, hence it lowers the energy density. Furthermore, silica reacts with other alkali metals such as potassium and forms alkali silicates that have a lower melting point, thereby increasing the slagging and deposition rates at lower temperatures (Wang et al., 2008). Manageable silica levels are difficult to estimate, since it depends on the levels of other alkali metals in the biomass. However, for many grasses, lowering silica levels at least below the $5 \%$ ash threshold would improve the thermochemical potential of these grasses.

Some have argued to include silicon as an "essential" element (Epstein, 1999) due to its important and diverse roles. Silica serves as a structural element, keeping leaves erect and stems from lodging. Its physiological roles include detoxifying $\mathrm{Al}, \mathrm{Mn}$, and Fe by binding with them and regulating $P$ uptake (Richmond and Sussman, 2003), decreasing transpiration and reducing water stress (Ahmad et al., 1992; Epstein, 1999) and in its protective role, it may provide a mechanical barrier that hinders diseases and pests (Winslow et al., 1997; Richmond and Sussman, 2003; Cotterill et al., 2007; Keeping et al., 2009). These roles of silica have been validated in many diverse species such as rice, sugarcane, barley, jute, tomato, cucumber and strawberry (Datnoff et al., 2001).

Although the second most abundant element in the world's soils, silicon is not always in a form available to plants (Sommer et al., 2006). Soil water concentrations of monosilicic acid $\left(\mathrm{H}_{4} \mathrm{SiO}_{4}\right)$, the plant available form of silica, vary from 0.1 to $0.6 \mathrm{mM}$ in most soils (Datnoff et al., 2001). Silica deficiency is rare, but in sandy and highly weathered soils, and intensely cultivated soils, silica application can improve yields (Datnoff et al., 2001; Ma and Takahashi, 2002). In most plants, silica, an uncharged molecule in biological conditions, is taken up with the water stream and diffuses through membranes, following the transpiration stream up the xylem (Mitani et al., 2005). It is deposited as "opal" or "phytoliths," more accurately called amorphous silica $\left(\mathrm{SiO}_{2}\right.$. $\mathrm{nH}_{2} \mathrm{O}$ ), usually where transpiration has caused the solution to become saturated-in the intercellular spaces and the bulliform cells. Deposition also occurs frequently in silica bodies, xylem cells, root endodermis cells, and in the cuticle silica double layer along the epidermis of leaf blades (Yoshida et al., 1962; Prychid et al., 2003). It is becoming clear that silica deposition can be a carefully engineered process directed by the plant, as temporal control of silica deposition in silica bodies demonstrates (Zhang et al., 2013).

Silica content of plants ranges from trace (less than $0.5 \%$ ) to small $(0.5-1 \%$, roughly corresponding to the amounts in the soil water), to high (1-15\%) amounts (Raven, 1983; Datnoff et al., 2001; Ma and Takahashi, 2002). Accumulation of high levels seems to require an active system of transporters. For example, rice accumulates high levels of silica via characterized transporters, including an aquaporin in root cells, an antiporter that uses the proton gradient to load silica into the xylem, and a passive transporter that moves silica from the xylem to the leaf (Ma et al., 2011). Several bioenergy feedstocks accumulate high silica levels (see Table 2) but the specific transporters are yet to be identified and the effects of modifying their production or activity are unknown. It is important to note for practical purposes additional silica may be introduced into the feedstock with soil contamination of the biomass.

While there is usually a correlation between soil-available silica and amounts of silica taken up by plants, there is large variation for the amount accumulated, even within a species. When grown the same soil, some varieties of rice always accumulate more silica than other varieties (Deren et al., 1992). In general, japonica rice varieties take up more silica than indica varieties, maybe because the japonica types were domesticated on silica deficient soils (Datnoff et al., 2001). Plants that are non-accumulators (corresponding to the trace levels discussed above) do not take up silica-even under high soil silica conditions. It is unclear why plants have adapted to maintain such different levels of silica. Cell specific deposition indicates that silica is under genetic control (Yoshida et al., 1962; Duan et al., 2005; Monti et al., 2008). Quantitative trait loci (QTL) have been mapped for silica concentration in various tissues (Wu et al., 2006; Dai et al., 2008) and there are hints that some disease resistance genes may actively modify silica levels (Li et al., 2012) and different types of silica deposition may have different roles (Isa et al., 2010).

Silica content is estimated in plant tissue by hydrofluoric acid extraction and a molybdenum blue assay (Saito et al., 2005) or by gravimetric techniques (Datnoff et al., 2001). Measurement is also possible with ICP-OES (El-Nashaar et al., 2009) and distribution within a tissue can be assessed by X-ray fluorescence spectroscopy (Datnoff et al., 2001). In all cases, care must be taken to avoid glassware that could introduce additional Si into the sample. Since the large majority of ash in many grasses is silica, crude measures of ash analysis can correlate with silica content. Additionally, ash can be predicted via NIR spectroscopy and these indirect methods (crude ash and NIR) might be optimized for high-throughput measurement of silica.

In conclusion, the observations of natural variation in silica content and the discovery of specific targets, the silica transporters, indicate the potential of silica levels as a target for biomass crop improvement. Indeed, in a study of ash levels across 144 species, Tao et al. identified silica content as a good target for optimized biomass (Tao et al., 2012a). A targeted approach might be to simultaneously decrease silica content: possibly by downregulating silica transporters, while upregulating lignin production to compensate for the loss of silica. However, it will be important to monitor plant performance as silica levels are manipulated because silica can be critically important for plant growth and yield. biomass (Jung et al., 2012; Wang and Dixon, 2012; Yang et al., 2012). This information can be the basis for development of molecular markers to improve the phenotype by breeding or to design gene constructs for improvement through biotechnology. This knowledge, frequently gained from model plants can be applied even to distantly related species by using comparative genomics approaches (Ficklin and Feltus, 2011). This is important because for some species, notably several emerging energy grasses, genetic tools are just being developed. As with all breeding efforts, agronomic considerations must be considered; that is, the plants must still be able to survive and produce an acceptable yield. In the following sections, we discuss the genetic and environmental control of traits related to thermochemical conversion properties. 


\section{CELLULOSE AND LIGNIN}

Often comprising more than $50 \%$ of the cell wall, cellulose and lignin have been well-studied and the enzymes involved in their synthesis are well understood (Boerjan et al., 2003; Endler and Persson, 2011). However, how these components are linked within the cell wall, and how the synthesis and modification are regulated are not well understood (Zhao and Dixon, 2011). There is a complex balance between cellulose and lignin levels, and the manipulation of genes involved in their biosynthesis sometimes leads to unexpected results (Gallego-Giraldo et al., 2011). Plants are surprisingly flexible, and can utilize a diverse set of precursors to build their cell walls. For example, Jensen and coworkers modified the native form of xyloglucan (a hemicellulose) in Arabidopsis without any apparent phenotypic consequences (Jensen et al., 2012). Yang and colleagues engineered plants to have thicker cell walls with more polysaccharides, but less lignin without negative consequences (Yang et al., 2012).

Research has focused on genes controlling the wall composition of the model dicot, Arabidopsis, or woody crops like poplar. However, to apply knowledge of these genes to more feedstocks, the findings will need to be validated in new crops. For example, lignin monomer composition differs between woody and herbaceous crops (Grabber et al., 2004; Buranov and Mazza, 2008). Gymnosperms have mostly G lignin while dicots have $G$ and $S$ and monocots generally have all three types. These monomers have different properties, including different estimated HHV (Amthor, 2003), and may influence the thermochemical properties of the biomass (Shen et al., 2010). It has been found that coniferous (mostly $\mathrm{G}$ ) lignin is more thermally-stable than deciduous (mostly S) lignin (Müller-Hagedorn et al., 2003), and this is likely because $G$ lignins contain more resistant linkages than $S$ lignins (Boerjan et al., 2003). Approaches to fine-tune lignin composition have been suggested (Weng et al., 2008). The ratio of these monomers, as well as the soluble phenolics, may have consequences as important as cellulose and lignin ratios (Gani and Naruse, 2007; Shen et al., 2009; Studer et al., 2011; Elumalai et al., 2012). Because lignin biosynthesis genes vary across plant families, and between dicots and monocots, (Xu et al., 2009), it is likely that other unexamined differences in lignin composition in crop species might exist (Xu et al., 2009). In addition to the three major lignin monomers, monocots contain relatively large amounts of soluble phenolics and the genes controlling these might be useful targets to modify cell wall composition (Ishii, 1997; Bartley et al., 2013; Molinari et al., 2013).

Beyond genetically controlled variation of wall composition within and between species, growth environment plays a large role. Adler and colleagues observed that lignin content increased from 10 to $33 \%$ between a fall and spring harvest of the same crop of switchgrass (Adler et al., 2006). Monono and colleagues observed differences in total yield, composition, and ethanol yield in switchgrass between locations and seasons (Monono et al., 2013). Miscanthus also displays variation in composition across environments (Allison et al., 2011). Switchgrass S, $\mathrm{G}$, and $\mathrm{H}$ monomer ratios show major differences when grown in the growth chamber, greenhouse or field (Mann et al., 2009), which is consistent with strong genotype by environment interactions (Hopkins et al., 1995; Lemus et al., 2002). Sugarcane internode composition changes over the growing season (Lingle and Thomson, 2011). Thus, although a viable focus, optimization of biomass through manipulation of wall lignin and cellulose composition and content will require not only an understanding of the genetic controls for these components, but also significant knowledge of the environmental component.

\section{MINERAL CONTENT AND ELEMENTAL ASH}

Elements commonly found in biomass ash are profiled in Table 2. There are major differences in the concentrations of these elements between woody and herbaceous crops, and herbaceous crops generally have more $\mathrm{N}, \mathrm{Cl}$, and $\mathrm{K}$, but less Ca than woody crops (Vassilev et al., 2010; Tao et al., 2012a). Though not essential for survival, $\mathrm{Si}$ is accumulated to high levels in many grasses, up to $10 \%$ dry weight (Epstein, 1999). Vassilev and colleagues find that levels of elements seem to exist in five associated groups in biomass, and these associations may have underlying biological significance: $\mathrm{C}-\mathrm{H}$; N-S-Cl; $\mathrm{Si}-\mathrm{Al}-\mathrm{Fe}-\mathrm{Na}-\mathrm{Ti}$; $\mathrm{Ca}-\mathrm{Mg}-\mathrm{Mn}$; and $\mathrm{K}-\mathrm{P}-\mathrm{S}-\mathrm{Cl}$ (Vassilev et al., 2010). Therefore, attempting to modulate $\mathrm{Ca}$ levels for example, might also impact $\mathrm{Mg}$ and $\mathrm{Mn}$ levels and it might be difficult to breed away from these associations. In addition to individual elemental associations, there is also evidence of a relationship between total ash content and biochemical constituents, with total ash content inversely proportional to lignin (Fahmi et al., 2007, 2008), and total ash proportional to cellulose ( $\mathrm{Lv}$ et al., 2010). It has been hypothesized that this relationship is due to overlap in the roles of lignin and mineral fraction with regard to mechanical stability and resistance to attack (Fahmi et al., 2007).

While the uptake, transport and roles of several of these mineral elements in plants are well understood (Taiz and Zeiger, 2006), little is known about the genes controlling variation for these traits (Mäser et al., 2001; Raboy, 2003; Ghandilyan et al., 2006). Uptake and distribution of these elements through the plant occurs via many different pathways, including uptake from the rhizosphere, transfers from roots to shoots, and remobilization among organs. These transport pathways can be both shared and opposing between elements, as indicated by positive and negative correlation of mineral and micronutrient phenotypes [reviewed by Ghandilyan et al. (2009)]. For example, Si is negatively correlated with Ca in some species (Nishimura et al., 1989), and reducing Si may simply increase $\mathrm{Ca}$ in plant tissues (and the $\mathrm{Ca}$ associated thermochemical issues). $\mathrm{Cl}$ content varies between stems and leaves of miscanthus (Lewandowski and Kicherer, 1997), and $\mathrm{Cl}$ and $\mathrm{Ca}$ variation has been observed in the bark, needles, and wood of various tree species (Werkelin et al., 2005). Tissue specific differences in other elements probably existindicating genetic control. Heritability for mineral content ranges from 10 to $90 \%$, so breeding for some elements will be more difficult than others (Ghandilyan et al., 2009). Understanding variation for these traits among cultivars of switchgrass is complicated by strong environmental interactions (Lemus et al., 2002; El-Nashaar et al., 2009), as is probably the case for other feedstocks.

Elemental concentrations also vary widely between and within species, by tissue type, and across harvest time and environments (Landström et al., 1996; Adler et al., 2006; Boateng et al., 2006; 
Christian et al., 2006; Nassi o Di Nasso et al., 2010; Baxter et al., 2012; Singh et al., 2012; Zhao et al., 2012b). Of considerable importance when focusing on crop improvement in elemental composition is that any attempt at improvement will be complicated by the interaction of these gene pathways with other traits essential for crop productivity, i.e., agronomic traits such as drought and salt tolerance, disease or pest resistance (Egilla et al., 2001; Dordas, 2008; Baxter et al., 2009, 2010). Because the genetics is complex and the potential implications on agronomic traits are serious, focus has been on reducing the impacts of these elements by other solutions, such as adjusting harvest time (Monti et al., 2008), allowing the minerals to leach out in the field before collection (Jenkins et al., 1996), and adding compounds to minimize reactions during thermochemical conversion (Van Loo and Koppejan, 2008).

\section{MOISTURE CONTENT}

Wet biomass from the field can contain greater than 50\% moisture on a wet basis, but this can vary greatly (Table 2 ), and intrinsic moisture (water tightly bound to biomass) is much lower. Although moisture content is an important component of the energy content, the literature on genetic variation and alteration of traits governing moisture content are sparse. In several species of willow, differences in moisture content of up to $16 \%$ exist and almost $40 \%$ of this variation is due to genotype (Mosseler et al., 1988). In rice, moisture content between 20 diverse varieties varied from 43 to $74 \%$ and broad sense heritability was found to be 0.6 (Jahn et al., 2011).

It is well known that species and varieties of plants vary in their ability to cope with drought stress (Zhu, 2002; Golldack et al., 2011). One strategy that plants employ is to manipulate the osmotic potential of their cells, and thus allow water to be maintained under drought conditions (McCann and Huang, 2008). It is through this mechanism that genetic control of the moisture content of the cells exists, and thus possibly the plant as a whole at harvest time. Many of the genes involved in these processes have been characterized (Bartels and Sunkar, 2005). There may also be significant correlations between moisture content and mineral content, since minerals ions are utilized to modulate the osmotic potential of the cells (Patakas et al., 2002; Arjenaki et al., 2012). In rice varieties studied by Jahn et al. (2011), a correlation between leaf ash but not stem ash and moisture content was observed, although these relationships have yet to be directly examined.

Clearly there is evidence that selection for moisture content is feasible but application of genetic approaches to improving biomass crops for moisture content has remained largely unexplored. As for mineral content, agronomic solutions to minimizing moisture content have been employed. For example, post-senescence drying reduced moisture content by $30 \%$ in miscanthus stems (Hodgson et al., 2010).

\section{OTHER IMPORTANT TRAITS}

Other traits highlighted in Figure 2A but not discussed thus far in this section include HHV, grindability, bulk density, as well as components of proximate and ultimate analysis. While some information exists about their relationship with biomass composition, little information exists about the genetic control of these traits. Bulk density may be influenced by cell wall changes (Wang et al., 2010) and variation in grindability has been observed among corn stover, straw, and hardwood (Cadoche and López, 1989). The first steps toward studying these might be to measure their variation across a species (a genome wide association mapping study, GWAS), or study their segregation in a genetic mapping population (a QTL study) (Mackay, 2001; Collard et al., 2005; Takeda and Matsuoka, 2008; Zhu et al., 2008). A critical component of both of these approaches is the ability to measure these traits in large numbers of plants in a high-throughput manner.

\section{POTENTIAL FOR HIGH-THROUGHPUT PHENOTYPING}

We have identified many of the feedstock traits important for thermochemical conversion and discussed the relationships between traits. In this section, we review how these traits are measured, and in cases where several methods exist, we highlight those methods which might be amenable to high-throughput phenotyping of many individual plants.

\section{BIOCHEMICAL ANALYSIS}

The most complete approach to quantifying the cell wall content is quantitative saccharification (also referred to as dietary fiber, Uppsala method, or NREL method). Water and ethanol soluble fractions are isolated, followed by hydrolysis and quantification of the component sugars, sugar degradation products, and organic acids by high performance liquid chromatography (HPLC) or gas chromatography mass spectroscopy (GC/MS) and acid soluble lignin with UV-vis spectroscopy. Starch is quantified and subtracted from cellulose, since it would contribute glucose monomers and inflate the cellulose component. Protein, ash and acid insoluble lignin (Klason lignin) are quantified from the remaining residue (Theander et al., 1995; Sluiter et al., 2010). Another common method originally developed to determine forage quality is called detergent fiber or the Van Soest method, and involves treating biomass with various concentrations of acids and bases to sequentially hydrolyze components of the cell wall, followed by acid insoluble lignin and ash determination (Van Soest et al., 1991; Uden et al., 2005). Each method highlighted here assumes the monomeric sugars are derived from certain polymers in the cell wall, and each method has its own set of biases (Moxley and Zhang, 2007; Wolfrum et al., 2009).

While any method is probably feasible for high-throughput given enough investment in lab time, equipment or automation (such as robotics), we highlight recent approaches in lignin quantification and monomer composition with pyrolysis molecular beam mass spectroscopy (pyMBMS) (Mann et al., 2009; Studer et al., 2011) or thioglycolic acid lignin (Suzuki et al., 2009). Cellulose, hemicellulose and lignin have been estimated with a thermogravimetric analyzer (TGA) which is essentially a microbalance inside a controlled-atmosphere furnace (Serapiglia et al., 2009). High-throughput glycome profiling of cell wall extracts detects presence or absence of specific polysaccharides but does not quantify the various components (Pattathil et al., 2012). Pretreatment and saccharification approaches (Gomez et al., 2010; Santoro et al., 2010) or ethanol yield (Lee et al., 
2012) directly test how amenable biomass is to enzymatic conversion, and indirectly provide information about the cell wall composition.

\section{PROXIMATE ANALYSIS}

Proximate analysis separates the biomass into moisture, VM, FC, and ash. This is accomplished through controlled heating of a ground sample in a furnace and observing mass lost during heating. VM and FC are determined after correcting for moisture and ash content. Proximate analysis can also be conducted in a single operation using a TGA. Heating value is also typically measured in the course of proximate analysis using bomb calorimetry, in which a biomass sample is fully combusted in a pure oxygen environment within a reaction vessel suspended in a water jacket; calorific value of the fuel is inferred from changes in the water temperature. HHV includes the energy released when the $\mathrm{H}_{2} \mathrm{O}$ produced during the combustion process condenses. An adjustment can be made since the energy due to water condensing is not captured in some systems - the adjusted value is the LHV.

While moisture content is part of standard proximate analysis procedure, it can also be evaluated by itself. The simplest, yet most time consuming method to assess moisture content is the oven dry method-moisture is removed by drying and the difference in mass is assumed to be moisture loss. These methods assume that the sample has been stored in an airtight container; otherwise moisture gain or loss (due to varying relative humidity of the storage environment) will have occurred between sample collection, and moisture determination. Often "as received" moisture is referred to in the literature-this is a meaningless value as it depends on the conditions that the sample underwent between the field and the lab and varies with humidity in the environment, and how long the plant was allowed to senesce in the field. Moisture content can also be estimated on a wet basis with handheld moisture meters (Jensen et al., 2006). These meters work by testing the conductance or capacitance of the material or various chemical means but only work in certain ranges of moisture (Bala, 1997). Biomass moisture is conceptually simple to understand and measure, but often goes unmeasured or unclearly reported, hampering our knowledge of the underlying genetic and environmental control.

\section{ULTIMATE ANALYSIS}

Profiling the individual elements is accomplished with approaches that measure electronic properties of elements (absorption, emission, and fluorescence spectroscopy) or techniques that measure nuclear properties (radioactivity, mass spectroscopy). Elemental analyzers available from many manufacturers either flash oxidize or pyrolyze the biomass and measure products such as $\mathrm{CO}_{2}, \mathrm{H}_{2} \mathrm{O}, \mathrm{NO}_{\mathrm{x}}$ in the exhaust gas via gas chromatography and thermal conductivity in order to stoichiometrically back-calculate the initial concentrations in the biomass (see standards in Figure 2B). Profiling elements in the ash fraction has traditionally been accomplished by solubilizing the ash and detection with atomic absorption spectroscopy (AAS). This involves ionizing atoms using a flame and measuring the portion of light absorbed by the elements as they pass through the detector (Dean et al., 1997; Hoenig et al., 1998).
When coupled with autosamplers, these instruments can be relatively high-throughput.

Recently, profiling the inorganic fraction in whole biomass (ionomics), has improved with advances in Inductively Coupled Plasma (ICP) techniques. These techniques ionize atoms in a plasma gas and measure emissions using Optical Emission Spectroscopy as the atoms fall to their ground state (ICPOES), or the ionized atoms are passed to a mass spectrometer (ICP-MS) (Salt et al., 2008). ICP-OES can also be called ICPAES (Atomic Emission Spectroscopy). Advantages with these approaches include sensitivity, small sample size, and the ability to quantify many elements from the same sample but quantification of some elements (notably Si; see Box 1 for further discussion) require special equipment and additional sample preparation.

\section{OTHER TRAITS}

Grindability is measured by recording the energy consumption of the equipment used to grind a sample to specified size (Mani et al., 2004; Abdullah and Wu, 2009). A standard procedure does not appear to exist but would be essential to develop before larger studies are undertaken because the trait is influenced by many factors including moisture content, particle size, and how tightly the biomass is packed before measurement (Lam et al., 2008; Chevanan et al., 2010). It should be possible to adapt the existing standard for testing and comparing different types of grinding equipment (ASTM E959) to compare different types of biomass using a standardized piece of equipment. Standard procedures exist for bulk density (Figure 2B), but are highly dependent on the initial particle size. Particle density, which excludes the air space between particles, is another technique to estimate density of biomass. This can be measured with a gas pycnometer that displaces the air between biomass particles with a known volume of gas (Sokhansanj et al., 2008).

\section{HIGH-THROUGHPUT PHENOTYPING: AUTOMATION AND INDIRECT MEASUREMENTS}

Phenotyping biomass to distinguish between genetic and environmental controls on individual bioenergy traits requires the characterization of large populations of plants, and some of the techniques described above are more appropriate for analyzing large sets of samples than others. Detergent fiber analysis has been somewhat automated with filter bag systems (Vogel et al., 1999). Robotic systems that can grind and weigh many samples at once exist to determine properties important for enzymatic conversion (Santoro et al., 2010). Traditionally, protein is quantified with dyes (Bradford, Lowry, etc), with UV-vis spectroscopy, or other techniques reviewed in Sapan et al. (1999) or Noble and Bailey (2009), but indirect methods that quantify N (such as the Kjeldahl method or elemental analyzers) simply use a conversion factor to estimate crude protein (Mosse, 1990). There are a number of automated proximate analyzers, elemental analyzers, and calorimeters available (e.g., Fu et al., 2011; Kumar et al., 2011; Smets et al., 2011), in which multiple samples can be loaded into racks and then analyzed automatically by the instrument.

Another approach to high-throughput phenotyping is the identification of correlations between the trait of interest and others traits that are more easily measured. For example, heating 
value can be estimated based on biochemical, proximate, or ultimate analysis through various equations, summarized in Sheng and Azevedo (2005). Interestingly, ultimate analysis is the most reliable approach-maybe in part due to variation in estimating biochemical or proximate properties. It should be highlighted that like many regression approaches, the sample set that is used to build the equation is critical and thus the equations may be plant species specific. Since grindability is ultimately a function of properties like moisture and composition, equations can be used to predict it in various types of biomass (Ghorbani et al., 2010; Miao et al., 2011).

A variety of properties can also be predicted from nondestructive high-throughput spectroscopic methods, particularly infrared (IR), often measured with an instrument capable of utilizing a Fourier Transform approach (FTIR), or raman spectroscopy which provides information complementary with FTIR, and Near Infrared (NIR) methods. IR spectroscopy measures the absorption of IR radiation by functional groups within compounds and may be used to directly fingerprint the compound, or in complex samples (such as biomass) a predictive model can be developed to quantify the biomass composition. NIR spectroscopy provides information through the combinations of fundamental bond vibrations (harmonics and overtones) in many compounds that absorb different wavelengths of NIR radiation depending on their resonance structure and penetrates deeper into the sample than IR (Reich, 2005). Because of the complex interactions in the NIR spectra, it is generally necessary to develop a predictive model to correlate spectra with a primary analytical method to predict composition and may not be as sensitive as IR methods. Spectra and primary analytical quantification of the trait of interest is collected on a diverse set of representative samples and this is used to derive a calibration equation using multivariate statistical methods such as partial least squares (PLS) or principal component analysis (PCA) to correlate the spectra with the primary analytical methods. An excellent example of the range of assays that can be utilized as analytical methods to build NIR models is presented by Vogel et al., 2010. The equation is tested on another subset of samples to ensure that it accurately predicts the trait of interest basely solely on the spectra obtained (Sanderson et al., 1996; Burns and Ciurczak, 2001).

While there is a large initial investment in developing a model, the ability to predict composition of new samples based only on quickly capturing spectral information makes these methods an attractive option. Consequently, spectroscopic methods have been used to estimate almost all the properties previously discussed. Based on detergent fiber calibration, NIR has predicted biochemical composition of sugarcane (Sabatier et al., 2012), rice (Jin and Chen, 2007), corn stover and switchgrass (Liu et al., 2010), miscanthus (Hodgson et al., 2010) and several other species. Dietary fiber calibration has also been used to predict detailed monomeric sugar composition of corn (Wolfrum and Sluiter, 2009) and miscanthus (Hayes, 2012). Proximate and ultimate analysis and heating value have been estimated for rice straw using NIR (Huang et al., 2008, 2009). FTIR models have successfully been used to estimate $\mathrm{N}$ content, heating value and alkali index of switchgrass and reed canary grass (Allison et al., 2009), and lignin and heating value in poplar (Zhou et al.,
2011). NIR has been used to estimate moisture, ash and heating value of spruce (Lestander and Rhén, 2005) as well as miscanthus and willow (Fagan et al., 2011) and heating value in sorghum and miscanthus (Roberts et al., 2011; Everard et al., 2012). Lestander et al., 2009 also show that NIR can even predict the energy required to pelletize sawdust, and NIR would likely have similar success in predicting the energy required to grind biomass. Though often omitted in methodological discussions, sample preparation can become the limiting step for any high-throughput phenotyping method. From this perspective, these may be less attractive due to necessary sample preparation steps. Both IR and NIR can utilize small sample sizes; $<10 \mathrm{mg}$ for IR and $<100 \mathrm{mg}$ for NIR (Laurens and Wolfrum, 2011) and while commonly the samples are ground, this is not always necessary (Penning et al., 2009). NIR is non-destructive, and through the use of various techniques [Attentuated Total Reflectance (ATR), Diffuse Reflectance (DR)], FTIR can also be non-destructive.

While research exploring the genetic basis for variation among these traits is often conducted in conditions that minimize the environmental variability (growth chambers and greenhouses), assessing the genetic and environmental interplay in field environments is essential to improving desirable traits in the new energy feedstocks. Recent efforts have begun to assess field populations with sensors that use various spectra of light and correlate with phenotypes such as plant height, biomass, drought tolerance and others (Montes et al., 2011; Normanly, 2012; White et al., 2012). These efforts need to be expanded to other bioenergy relevant traits. Non-destructive spectral imaging could be adapted from current applications in precision fertilizer application (Haboudane et al., 2002) to other compositional properties. These approaches might be used to predict heating value or even moisture content from spectral-based elemental composition (Seelig et al., 2008).

In summary, several primary analysis techniques might be amenable to high-throughput, mostly by automating the steps involved or multiplexing to process many samples at once. However there appears to be real promise in leveraging regression or multivariate approaches to predict key properties like heating value and ash based on data from elemental analyzers or spectral approaches.

\section{CONCLUSION}

Thermochemical conversion of biomass is an increasingly viable way to use bioenergy crops and agricultural residues to fulfill energy needs. Plant biologists and engineers both have important roles to play in the design of thermochemical bioenergy systems that result in appropriate pairings of biomass feedstocks and conversion technologies, though each group is limited by the constraints of their respective sub-systems. For engineers, this involves the design of efficient supply chains and conversion technologies that are robust to natural variations in biomass properties while minimizing energy use, material costs, and harmful emissions. Preprocessing technologies such as baling straw (Lötjönen and Paappanen, 2013) or torrefaction (Robbins et al., 2012) can also contribute to feedstock standardization. For biologists, this involves optimizing favorable biomass traits without 
compromising the plant's ability to survive in a sometimes hostile ecosystem. Natural genetic variation is a powerful resource for the improvement of bioenergy traits (both enzymatic and thermochemical) in feedstock plants, and the biological community has made great progress in understanding and manipulating the genetic pathways behind various relevant plant traits. Conversely, if natural variation for a trait is low, it is likely that modifications would incur serious consequences for the plant.

We find sufficient variation in lignin and evidence for potential genetic manipulation and several relatively high-throughput measurement methods. Unlike enzymatic systems where lignin is highly problematic, its role is more nuanced in thermochemical conversion systems where it is associated with higher HHV feedstocks, but changes to product distributions that may or may not be desirable. From an agronomic standpoint, increased lignin might be more feasible than reduced lignin due to the important roles it plays in physical stability and protection against pathogens. While less clear how amenable ash content is to genetic manipulation, we find larger variation in ash and variation in many of the minerals that contribute to ash and suitable methods to phenotype them. Silica is a special problem with grasses, but could be addressed by exploiting the huge diversity observed within and among species, particularly using knowledge of the transporters with which its deposition might be controlled. Reducing silica in grasses and increasing lignin to mitigate the associated agronomic impacts might lead to an optimal thermochemical feedstock. However, the relationship between lignin, ash, and thermochemical conversion products is still not well understood, and additional systematic experimentation or metaanalysis will be necessary to confirm these strategies. The most biologically interesting traits may not be the traits that will have the greatest economic and lifecycle impact. Efforts to determine heritability in more abstract traits such as moisture content, grindability and bulk density would be valuable next steps based on observations of genetic variation seen in rice and other species, though high-throughput methods to measure grindability and density do not currently exist.

Biochemical and proximate/ultimate analysis are both equally valid paradigms for describing a kilogram of biomass, though the latter does present two distinct advantages in the context of feedstocks for thermochemical bioenergy production. Predicting biomass properties such as HHV from biochemical analysis results is challenging (likely because of biases associated with different measurement methods), while regressions based on ultimate analysis appears to work even across diverse data sets (Sheng and Azevedo, 2005). Secondly, ultimate analysis may prove to

\section{REFERENCES}

Abdullah, H., and Wu, H. (2009). Biochar as a Fuel: 1. Properties and grindability of biochars produced from the pyrolysis of mallee wood under slow-heating conditions. Energy Fuels 23, 4174-4181. doi: 10.1021/ef900494t

Adler, P. R., Sanderson, M. A., Boateng, A. A., Weimer, P. J., and Jung, H.-J. G. (2006). Biomass yield and biofuel quality of switchgrass harvested in fall or spring. Agron. J. 98, 1518. doi: 10.2134/agronj2005.0351

Ahmad, R., Zaheer, S. H., and Ismail, S. (1992). Role of silicon in salt tolerance of wheat (Triticum aestivum L.). Plant Sci. 85, 43-50. doi: $\quad 10.1016 / 0168-9452(92)$ 90092-Z

Albersheim, P., Darvill, A., Roberts, K., Sederoff, R., and Staehelin,

be more amenable to high-throughput phenotyping efforts, with automated elemental analyzers and spectroscopy as promising direct and indirect methods for the measurement of many important properties. While initial investments in equipment and model development can be high, the establishment of core facilities and modeling equations for thermochemical characterization of biomass can make these approaches more accessible.

While this review has focused on genetic approaches to crop improvement, agricultural management (including what fertilizers to apply, when to harvest, and how to store the biomass) is critical and will impact the characteristics of the biomass, and ultimately, the lifecycle of the system (Robbins et al., 2012; Davis et al., 2013; Wilson et al., 2013). Teasing out genetic variation and environmental effects has been and will continue to be a major challenge. Careful observation of all key traits, including agronomic traits related to sustainable crop production, will need to be done-some pathways are common to some molecules or elements, and plants may need to compensate for composition changes in unexpected ways. It is critical to analyze results in the context of the environment and avoid sweeping generalizations attributed to a certain species or specific transgenic plant (Voelker et al., 2010). Moving from the individual plant in the greenhouse to a field of plants will present new challenges and new surprises. Can we make valid conclusions from biomass composition at the field level, or will understanding genetic control require phenotyping at the resolution of individual plant organs or even cell types? Large-scale high-throughput phenotyping is the next frontier in plant science, and this review can help biologists and engineers prioritize traits for next generation bioenergy crop improvement. Beyond bioenergy, the food, forage, pulp, and paper industries will benefit as we fine-tune all aspects of biomass composition.

\section{ACKNOWLEDGMENTS}

We would like to thank Al Weimer, Dan Bush, and Jessica Tryner for critical review and comments on the manuscript. The authors were supported by an NSF IGERT fellowship to Tanger and Field, and grants from the Office of Science (Biological and Environmental Research), the US Department of Energy (DE-FG02-08ER64629), USDA National Institute of Food and Agriculture (2008-35504-04852), USAID-IRRI Linkage Program (DRPC2011-42), and CSU Clean Energy Supercluster to Tanger, Jahn and Leach. Inspiration for the grass graphic used in Figure 2 came from www.dragonartz.net. Colorado State University Libraries Open Access Research and Scholarship Fund provided funding to defray publication costs.

A. (2010). Plant Cell Walls, 1st Edn. New York, NY: Garland Science.

Allison, G. G., Morris, C., CliftonBrown, J., Lister, S. J., and Donnison, I. S. (2011). Genotypic variation in cell wall composition in a diverse set of 244 accessions of Miscanthus. Biomass Bioenergy 35, 4740-4747. doi: 10.1016/j.biombioe.2011.10.008
Allison, G. G., Morris, C., Hodgson, E., Jones, J., Kubacki, M., Barraclough, T., et al. (2009). Measurement of key compositional parameters in two species of energy grass by Fourier transform infrared spectroscopy. Bioresour. Technol. 100, 6428-6433. doi: $\quad 10.1016 /$ j.biortech.2009. 07.015

Allison, G. G., Robbins, M. P., Carli, J., Clifton-Brown, J. C., and 
Donnison, I. S. (2010). "Designing biomass crops with improved calorific content and attributes for burning: a UK perspective," in Plant Biotechnology for Sustainable Production of Energy and Coproducts, eds P. N. Mascia, J. Scheffran, and J. M. Widholm (Berlin; Heidelberg: Springer Berlin Heidelberg), 25-55.

Amthor, J. S. (2003). Efficiency of lignin biosynthesis: a quantitative analysis. Ann. Bot. 91, 673-695. doi: 10.1093/aob/mcg073

Arabhosseini, A., Huisman, W., and Müller, J. (2010). Modeling of the equilibrium moisture content (EMC) of Miscanthus (Miscanthus $\times$ giganteus). Biomass Bioenergy 34, 411-416. doi: 10.1016/j.biombioe.2009.12.004

Arjenaki, F. G., Jabbari, R., and Morshedi, A. (2012). Evaluation of drought stress on relative water content, chlorophyll content and mineral elements of wheat (Triticum aestivum L.) varieties. Int. J. Agric. Crop Sci. 4, 726-729.

Babu, B. V. (2008). Biomass pyrolysis: a state-of-the-art review. Biofuels Bioprod. Bioref. 2, 393-414. doi: 10.1002/bbb. 92

Bailis, R. (2009). Modeling climate change mitigation from alternative methods of charcoal production in Kenya. Biomass Bioenergy 33, 1491-1502. doi: 10.1016/j.biombioe.2009.07.001

Bala, B. K. (1997). Drying and Storage of Cereal Grains. Enfield, NH: Science Publishers.

Bartels, D., and Sunkar, R. (2005). Drought and salt tolerance in plants. Crit. Rev. Plant Sci. 24, 23-58. doi: 10.1080/07352680590910410

Bartley, L. E., Peck, M. L., Kim, S.-R., Ebert, B., Maniseri, C., Chiniquy, D., et al. (2013). Overexpression of a BAHD acyltransferase, OsAt10, alters rice cell wall hydroxycinnamic acid content and saccharification. Plant Physiol. 161, 1615-1633. doi: 10.1104/pp.112. 208694

Baxter, I., Brazelton, J. N., Yu, D., Huang, Y. S., Lahner, B., Yakubova, E., et al. (2010). A Coastal cline in sodium accumulation in Arabidopsis thaliana is driven by natural variation of the sodium transporter AtHKT1;1. PLoS Genet. 6:e1001193. doi: $\quad 10.1371 /$ journal.pgen. 1001193

Baxter, I., Hermans, C., Lahner, B., Yakubova, E., Tikhonova, M., Verbruggen, N., et al. (2012). Biodiversity of mineral nutrient and trace element accumulation in Arabidopsis thaliana.
PLoS ONE 7:e35121. doi: 10.1371/ journal.pone. 0035121

Baxter, I., Hosmani, P. S., Rus, A., Lahner, B., Borevitz, J. O., Muthukumar, B., et al. (2009). Root suberin forms an extracellular barrier that affects water relations and mineral nutrition in Arabidopsis. PLoS Genet. 5:e1000492. doi: 10.1371/journal.pgen.1000492

Baxter, L. (2005). Biomass-coal co-combustion: opportunity for affordable renewable energy. Fuel 84, 1295-1302. doi: 10.1016/j.fuel.2004.09.023

Boateng, A. A., Hicks, K. B., and Vogel, K. P. (2006). Pyrolysis of switchgrass (Panicum virgatum) harvested at several stages of maturity. J. Anal. Appl. Pyrolysis 75, 55-64. doi: 10.1016/j.jaap.2005.03.005

Boerjan, W., Ralph, J., and Baucher, M. (2003). Lignin biosynthesis. Annu. Rev. Plant Biol. 54, 519-546. doi: 10.1146/annurev.arplant.54.031902. 134938

Boerrigter, H., and Rauch, R. (2005). "Chapter 10 Syngas production and utilisation," in Handbook Biomass Gasification, ed. H. A. M. Knoef (The Netherlands: Biomass Technology Group (BTG)), 211-230.

Borgwardt, R. (1999). Transportation fuel from cellulosic biomass: a comparative assessment of ethanol and methanol options. J. Power Energy 213, 399-407. doi: 10.1243/0957650991537770

Botha, T., and von Blottnitz, H. (2006). A comparison of the environmental benefits of bagasse-derived electricity and fuel ethanol on a life-cycle basis. Energy Policy 34, 2654-2661. doi: 10.1016/j.enpol.2004.12.017

Brar, J. S., Singh, K., Wang, J., and Kumar, S. (2012). Cogasification of coal and biomass: a review. Int. J. Forest. Res. 2012, 1-10. doi $10.1155 / 2012 / 363058$

Bridgwater, A. V. (2012). Review of fast pyrolysis of biomass and product upgrading. Biomass Bioenergy 38, 68-94. doi: 10.1016/j.biombioe. 2011.01.048

Bridgwater, A. V., Toft, A. J., and Brammer, J. G. (2002). A technoeconomic comparison of power production by biomass fast pyrolysis with gasification and combustion. Renew. Sustain. Energy Rev. 6, 181-246. doi: 10.1016/S13640321(01)00010-7

Brown, R. C. (ed.). (2011). Thermochemical Processing of Biomass: Conversion into Fuels, Chemicals and Power, 1st Edn. Chichester: Wiley. doi: 10.1002/ 9781119990840
Buranov, A. U., and Mazza, G. (2008). Lignin in straw of herbaceous crops. Ind. Crops Prod. 28, 237-259. doi 10.1016/j.indcrop.2008.03.008

Burns, D. A., and Ciurczak, E. W (2001). Handbook of Near-Infrared Analysis. Boca Raton, FL: CRC Press.

Butler, E., Devlin, G., Meier, D., and McDonnell, K. (2011). A review of recent laboratory research and commercial developments in fast pyrolysis and upgrading. Renew. Sustain. Energy Rev. 15, 4171-4186. doi: 10.1016/j.rser.2011. 07.035

Cabiles, D. M., Angeles, O. R., JohnsonBeebout, S. E., Sanchez, P. B. and Buresh, R. J. (2008). Faster residue decomposition of brittle stem rice mutant due to finer breakage during threshing. Soil Tillage Res. 98, 211-216. doi 10.1016/j.still.2007.12.004

Cadoche, L., and López, G. D. (1989). Assessment of size reduction as a preliminary step in the production of ethanol from lignocellulosic wastes. Biol. Waste. 30, 153-157. doi: 10.1016/0269-7483 (89)90069-4

Campbell, J. E., Lobell, D. B., and Field, C. B. (2009). Greater transportation energy and GHG offsets from bioelectricity than ethanol. Science 324, 1055-1057. doi: 10.1126/science.1168885

Carley, S. (2009). State renewable energy electricity policies: an empirical evaluation of effectiveness. Energy Policy 37, 3071-3081. doi: 10.1016/j.enpol.2009.03.062

Carpenter, D. L., Bain, R. L., Davis, R. E., Dutta, A., Feik, C. J., Gaston, K. R., et al. (2010). Pilot-scale gasification of corn stover, switchgrass, wheat straw, and wood: 1 . Parametric study and comparison with literature. Ind. Eng. Chem. Res. 49, 1859-1871.

Carroll, A., and Somerville, C. (2009). Cellulosic biofuels. Annu. Rev. Plant Biol. 60, 165-182. doi: $\quad 10.1146 /$ annurev.arplant.043 008.092125

Cherubini, F., Bird, N. D., Cowie, A., Jungmeier, G., Schlamadinger, B. and Woess-Gallasch, S. (2009). Energy- and greenhouse gas-based LCA of biofuel and bioenergy systems: key issues, ranges and recommendations. Resour. Conserv. Recycl. 53, 434-447. doi 10.1016/j.resconrec.2009.03.013

Chevanan, N., Womac, A. R., Bitra, V. S. P., Igathinathane, C., Yang, Y. T., Miu, P. I., et al. (2010). Bulk density and compaction behavior of knife mill chopped switchgrass, wheat straw, and corn stover. Bioresour. Technol. 101, 207-214. doi: 10.1016/j.biortech.2009.07.083 Christian, D. G., Yates, N. E., and Riche, A. B. (2006). The effect of harvest date on the yield and mineral content of Phalaris arundinacea L. (reed canary grass) genotypes screened for their potential as energy crops in southern England. J. Sci. Food Agric. 86, 1181-1188. doi: 10.1002/jsfa. 2437

Clifton-Brown, J. C., and Lewandowski, I. (2002). Screening Miscanthus genotypes in field trials to optimise biomass yield and quality in Southern Germany. Eur. J. Agron. 16, 97-110. doi: 10.1016/S11610301(01)00120-4

Collard, B. C. Y., Jahufer, M. Z. Z., Brouwer, J., and Pang, E. C. K. (2005). An introduction to markers, quantitative trait loci (QTL) mapping and marker-assisted selection for crop improvement: the basic concepts. Euphytica 142, 169-196. doi: 10.1007/s10681-0051681-5

Coovattanachai, N. (1989). Biomass gasification research and field developments by the Prince of Songkla University, Thailand. Biomass 18, 241-271. doi: 10.1016/0144-4565 (89)90036-X

Cotterill, J. V., Watkins, R. W., Brennon, C. B., and Cowan, D. P. (2007) Boosting silica levels in wheat leaves reduces grazing by rabbits. Pest Manag. Sci. 63, 247-253. doi: 10.1002/ps.1302

Couhert, C., Commandre, J.-M., and Salvador, S. (2009). Is it possible to predict gas yields of any biomass after rapid pyrolysis at high temperature from its composition in cellulose, hemicellulose and lignin. Fuel 88, 408-417. doi: 10.1016/j.fuel.2008. 09.019

Cummer, K. R., and Brown, R. C. (2002). Ancillary equipment for biomass gasification. Biomass Bioenergy 23, 113-128. doi: 10.1016/S0961-9534(02)00038-7

Dai, W. M., Zhang, K. Q., Wu, J. R., Wang, L., Duan, B. W., Zheng, K. L., et al. (2008). Validating a segment on the short arm of chromosome 6 responsible for genetic variation in the hull silicon content and yield traits of rice. Euphytica 160 317-324. doi: 10.1007/s10681-0079501-8

Datar, R. P., Shenkman, R. M., Cateni, B. G., Huhnke, R. L., and Lewis, R. S. (2004). Fermentation of biomassgenerated producer gas to ethanol. Biotechnol. Bioeng. 86, 587-594. doi 10.1002/bit.2007 
Datnoff, L. E., Snyder, G. H., and Korndörfer, G. H. (eds.). (2001). Silicon in Agriculture, Vol. 8, 1st Edn. New York, NY: Elsevier Science.

Davis, S. C., Boddey, R. M., Alves, B. J. R., Cowie, A. L., George, B. H., Ogle, S. M., et al. (2013). Management swing potential for bioenergy crops. GCB Bioenergy. doi: 10.1111/gcbb. 12042. [Epub ahead of print].

Dayton, D. C., Belle-Oudry, D., and Nordin, A. (1999). Effect of coal minerals on chlorine and alkali metals released during biomass/coal cofiring. Energy Fuels 13, 1203-1211. doi: 10.1021/ef9 900841

Dean, J. R., Ando, D. J., and Metcalfe, E. (1997). Atomic Absorption and Plasma Spectroscopy. 2nd Edn. Published on behalf of ACOL (University of Greenwich) by J. Wiley, New York, NY.

Demirbaş, A. (2001). Relationships between lignin contents and heating values of biomass. Energy Convers. Manage. 42, 183-188. doi: 10.1016/ S0196-8904(00)00050-9

Demirbaş, A. (2003a). Relationships between lignin contents and fixed carbon contents of biomass samples. Energy Convers. Manage. 44, 1481-1486.

Demirbaş, A. (2003b). Sustainable cofiring of biomass with coal. Energy Convers. Manage. 44, 1465-1479.

Demirbas, A. (2004). Combustion characteristics of different biomass fuels. Prog. Energy. Combust. Sci. 30, 219-230. doi: 10.1016/j.pecs. 2003.10.004

Demirbas, A. (2007). Progress and recent trends in biofuels. Prog. Energy Combust. Sci. 33, 1-18. doi: 10.1016/j.pecs.2006.06.001

Deren, C. W., Datnoff, L. E., and Snyder, G. H. (1992). Variable silicon content of rice cultivars grown on everglades histosols. J. Plant Nutr. 15, 2363-2368. doi: $10.1080 / 01904169209364480$

DOE. (2009). Biofuels Strategic Plan. Available online at: http://science. energy.gov/ /media/ber/pdf/biofue ls_strategic_plan.pdf (Accessed December 10, 2012).

DOE. (2011). US Billion-Ton Update: Biomass Supply for a Bioenergy and Bioproducts Industry. Oak Ridge, TN: Oak Ridge National Laboratory.

DOE DSIRE. (2012). Available online at: http://www.dsireusa.org/ summarymaps/index.cfm?ee $=0$ and $\mathrm{RE}=0$ (Accessed November 3, 2012).

Dordas, C. (2008). Role of nutrients in controlling plant diseases in sustainable agriculture. A review.
Agron. Sustain. Dev. 28, 33-46. doi: 10.1051/agro:2007051

Duan, B. W., Zhuang, J. Y., Zhang, K. Q., Cai, R., Dai, W. M., and Zheng, K. L. (2005). Genetic dissection of silicon content in different organs of rice. Crop Sci. 45, 1345-1352. doi: 10.2135/cropsci2004.0505

Egilla, J. N., Davies, F. T. Jr., and Drew, M. C. (2001). Effect of potassium on drought resistance of Hibiscus rosa-sinensis cv. Leprechaun: plant growth, leaf macro- and micronutrient content and root longevity. Plant Soil 229, 213-224. doi: 10.1023/A:100488 3032383

EIA. (2011). International Energy Outlook 2011. Energy Information Administration, Office of Integrated Analysis and Forecasting. Washington, DC: US Department of Energy.

EIA. (2012). Most states have Renewable Portfolio Standards. Available online at: http://www.eia.gov/ todayinenergy/detail.cfm?id $=4850$ (Accessed November 3, 2012).

El-Nashaar, H. M., Banowetz, G. M., Griffith, S. M., Casler, M. D., and Vogel, K. P. (2009). Genotypic variability in mineral composition of switchgrass. Bioresour. Technol. 100, 1809-1814. doi: 10.1016/j.biortech.2008.09.058

Elumalai, S., Tobimatsu, Y., Grabber, J. H., Pan, X., and Ralph, J. (2012). Epigallocatechin gallate incorporation into lignin enhances the alkaline delignification and enzymatic saccharification of cell walls. Biotechnol. Biofuels 5, 59. doi: 10.1186/17546834-5-59

Endler, A., and Persson, S. (2011) Cellulose synthases and synthesis in Arabidopsis. Mol. Plant 4, 199-211.

Energy Independence and Security Act of 2007 (EISA). (2007). Pub. L. No. 110-140, 121 Stat. 1492, 1783-84 (Dec. 19, 2007), codified at 42 U.S.C. $\$ 17381$.

Energy Research Centre of the Netherlands. (2012). Phyllis2, database for biomass and waste. Available online at: http://www.ecn. nl/phyllis2 (Accessed December 22, 2012).

Epstein, E. (1999). Silicon. Annu. Rev. Plant Physiol. Plant Mol. Biol. 50, 641-664. doi: 10.1146/ annurev.arplant.50.1.641

Everard, C. D., McDonnell, K. P., and Fagan, C. C. (2012). Prediction of biomass gross calorific values using visible and near infrared spectroscopy. Biomass Bioenergy 45 203-211. doi: 10.1016/j.biombioe. 2012.06.007
Fagan, C. C., Everard, C. D., and McDonnell, K. (2011). Prediction of moisture, calorific value, ash and carbon content of two dedicated bioenergy crops using nearinfrared spectroscopy. Bioresour. Technol. 102, 5200-5206. doi: 10.1016/j.biortech.2011.01.087

Fahmi, R., Bridgwater, A. V., Darvell, L. I., Jones, J. M., Yates, N., Thain, S., et al. (2007). The effect of alkali metals on combustion and pyrolysis of Lolium and Festuca grasses, switchgrass and willow. Fuel 86, 1560-1569. doi: 10.1016/j.fuel. 2006.11.030

Fahmi, R., Bridgwater, A. V., Donnison, I., Yates, N., and Jones, J. M. (2008). The effect of lignin and inorganic species in biomass on pyrolysis oi yields, quality and stability. Fuel 87 1230-1240. doi: 10.1016/j.fuel. 2007.07.026

Feltus, F. A., and Vandenbrink, J. P. (2012). Bioenergy grass feedstock: current options and prospects for trait improvement using emerging genetic, genomic, and systems biology toolkits. Biotechnol. Biofuels 5 , 80. doi: $10.1186 / 1754-6834-5-80$

Ficklin, S. P., and Feltus, F. A. (2011) Gene coexpression network alignment and conservation of gene modules between two grass species: maize and rice. Plant Physiol. 156, 1244. doi: 10.1104/pp.111. 173047

Field, J. L., Keske, C. M. H., Birch, G. L., DeFoort, M. W., and Cotrufo, M. F. (2013). Distributed biochar and bioenergy coproduction: a regionally specific case study of environmental benefits and economic impacts. GCB Bioenergy 5, 177-191. doi: 10.1111/gcbb. 12032

Frohlich, C. (2012). Two-year survey comparing earthquake activity and injection-well locations in the Barnett Shale, Texas. Proc. Natl. Acad. Sci. U.S.A. 109, 13934-13938. doi: 10.1073/pnas. 1207728109

Fu, P., Yi, W., Bai, X., Li, Z., Hu, S., and Xiang, J. (2011). Effect of temperature on gas composition and char structural features of pyrolyzed agricultura residues. Bioresour. Technol. 102, 8211-8219. doi: 10.1016/j.biortech. 2011.05.083

Gallego-Giraldo, L., Jikumaru, Y., Kamiya, Y., Tang, Y., and Dixon, R. A. (2011). Selective lignin downregulation leads to constitutive defense response expression in alfalfa (Medicago sativa L.) New Phytol. 190, 627-639. doi 10.1111/j.1469-8137.2010.03621.x
Gani, A., and Naruse, I. (2007). Effect of cellulose and lignin content on pyrolysis and combustion characteristics for several types of biomass. Renew. Energy 32, 649-661. doi: $\quad$ 10.1016/j.renene.2006. 02.017

Gaul, M. (2012). An analysis model for small-scale rural energy service pathways-applied to Jatropha-based energy services in Sumbawa, Indonesia. Energy Sustain. Dev. 16, 283-296. doi: 10.1016/j.esd.2012.05.001

Ghandilyan, A., Ilk, N., Hanhart, C., Mbengue, M., Barboza, L., Schat, H., et al. (2009). A strong effect of growth medium and organ type on the identification of QTLs for phytate and mineral concentrations in three Arabidopsis thaliana RIL populations. J. Exp. Bot. 60, 1409-1425. doi: 10.1093/jxb/ erp084

Ghandilyan, A., Vreugdenhil, D., and Aarts, M. G. M. (2006). Progress in the genetic understanding of plant iron and zinc nutrition. Physiol. Plantarum 126, 407-417. doi: 10.1111/j.1399-3054.2006.00646.x

Ghorbani, Z., Masoumi, A. A., and Hemmat, A. (2010). Specific energy consumption for reducing the size of alfalfa chops using a hammer mill. Biosyst. Eng. 105, 34-40. doi: 10.1016/j.biosystemseng.2009. 09.006

Giuntoli, J., Boulamanti, A. K., Corrado, S., Motegh, M., Agostini, A., and Baxter, D. (2012). Environmental impacts of future bioenergy pathways: the case of electricity from wheat straw bales and pellets. GCB Bioenergy doi: 10.1111/gcbb.12012. [Epub ahead of print].

Golldack, D., Lüking, I., and Yang, O. (2011). Plant tolerance to drought and salinity: stress regulating transcription factors and their functional significance in the cellular transcriptional network. Plant Cell Rep. 30, 1383-1391. doi: 10.1007/s00299011-1068-0

Gomez, L. D., Whitehead, C., Barakate, A., Halpin, C., and McQueenMason, S. J. (2010). Automated saccharification assay for determination of digestibility in plant materials. Biotechnol. Biofuels 3, 1-12. doi: 10.1186/1754-6834-3-23

Gonzalez, R., Daystar, J., Jett, M., Treasure, T., Jameel, H., Venditti, R., et al. (2012). Economics of cellulosic ethanol production in a thermochemical pathway for softwood, hardwood, corn stover and switchgrass. Fuel 
Process. Technol. 94, 113-122. doi: 10.1016/j.fuproc.2011.10.003

Goyal, H. B., Seal, D., and Saxena, R. C. (2008). Bio-fuels from thermochemical conversion of renewable resources: a review. Renew. Sustain. Energy Rev. 12, 504-517. doi: 10.1016/j.rser.2006. 07.014

Grabber, J. H., Ralph, J., Lapierre, C., and Barrière, Y. (2004). Genetic and molecular basis of grass cell-wall degradability. I. Lignincell wall matrix interactions. C. R. Biol. 327, 455-465. doi: 10.1016/j.crvi.2004.02.009

Haboudane, D., Miller, J. R., Tremblay, N., Zarco-Tejada, P. J., and Dextraze, L. (2002). Integrated narrow-band vegetation indices for prediction of crop chlorophyll content for application to precision agriculture. Remote Sens. Environ. 81, 416-426. doi: 10.1016/S0034-4257 (02)00018-4

Hayes, D. J. M. (2012). Development of near infrared spectroscopy models for the quantitative prediction of the lignocellulosic components of wet Miscanthus samples. Bioresour. Technol. 119, 393-405. doi: 10.1016/j.biortech. 2012.05.137

Helsel, Z. R., and Wedin, W. (1981). Direct combustion energy from crops and crop residues produced in Iowa. Energy Agric. 1, 317-329. doi: 10.1016/0167-5826(81)90028-0

Hiloidhari, M., and Baruah, D. C. (2011). Rice straw residue biomass potential for decentralized electricity generation: a GIS based study in Lakhimpur district of Assam, India. Energy Sustain. Dev. 15, 214-222. doi: 10.1016/j.esd.2011. 05.004

Hodgson, E. M., Lister, S. J., Bridgwater, A. V., Clifton-Brown, J., and Donnison, I. S. (2010). Genotypic and environmentally derived variation in the cell wall composition of Miscanthus in relation to its use as a biomass feedstock. Biomass Bioenergy 34, 652-660. doi: $\quad$ 10.1016/j.biombioe.2010. 01.008

Hoenig, M., Baeten, H., Vanhentenrijk, S., Vassileva, E., and Quevauviller, P. (1998). Critical discussion on the need for an efficient mineralization procedure for the analysis of plant material by atomic spectrometric methods. Anal. Chim. Acta 358, 85-94. doi: 10.1016/S00032670(97)00594-1

Hopkins, A. A., Vogel, K. P., Moore, K. J., Johnson, K. D., and Carlson, I. T. (1995). Genotype effects and genotype by environment interactions for traits of elite switchgrass populations. Crop Sci. 35, 125-132. doi: 10.2135/cropsci1995.0011183X003500010023x

Huang, C., Han, L., Yang, Z., and Liu, X. (2009). Ultimate analysis and heating value prediction of straw by near infrared spectroscopy. Waste Manage. 29, 1793-1797. doi: $\quad$ 10.1016/j.wasman.2008. 11.027

Huang, C. J., Han, L. J., Liu, L., and Yang, Z. L. (2008). Proximate analysis and calorific value estimation of rice straw by near infrared reflectance spectroscopy. J. Energy Inst. 81, 153-157. doi: $10.1179 / 174602208 \times 330284$

Huber, G. W., Iborra, S., and Corma, A. (2006). Synthesis of transportation fuels from biomass: chemistry, catalysts, and engineering. Chem. Rev. 106, 4044-4098. doi: $10.1021 / \mathrm{cr} 068360 \mathrm{~d}$

Isa, M., Bai, S., Yokoyama, T., Ma, J., Ishibashi, Y., Yuasa, T., et al. (2010). Silicon enhances growth independent of silica deposition in a lowsilica rice mutant, Lsil. Plant Soil 331, 361-375. doi: 10.1007/s11104009-0258-9

Ishii, T. (1997). Structure and functions of feruloylated polysaccharides. Plant Sci. 127, 111-127. doi: 10.1016/S0168-9452(97)00130-1

Jahn, C. E., McKay, J. K., Mauleon, R., Stephens, J., McNally, K. L., Bush, D. R., et al. (2011). Genetic variation in biomass traits among 20 diverse rice varieties. Plant Physiol. 155, 157-168. doi: 10.1104/pp.110.165654

Jenkins, B. M., Bakker, R. R., and Wei, J. B. (1996). On the properties of washed straw. Biomass Bioenergy 10, 177-200. doi: 10.1016/09619534(95)00058-5

Jenkins, B. M., Baxter, L. L., Miles, T. R. Jr., and Miles, T. R. (1998). Combustion properties of biomass. Fuel Process. Technol. 54, 17-46. doi: $\quad 10.1016 / S 0378-3820(97)$ 00059-3

Jensen, J. K., Schultink, A., Keegstra, K., Wilkerson, C. G., and Pauly, M. (2012). RNA-Seq analysis of developing nasturtium seeds (Tropaeolum majus): identification and characterization of an additional galactosyltransferase involved in xyloglucan biosynthesis. Mol. Plant 5, 984-992. doi: $10.1093 / \mathrm{mp} / \mathrm{sss} 032$

Jensen, P. D., Hartmann, H., Böhm, T., Temmerman, M., Rabier, F., and Morsing, M. (2006). Moisture content determination in solid biofuels by dielectric and NIR reflection methods.
Biomass Bioenergy 30, 935-943. doi: 10.1016/j.biombioe.2006.06.005

Jin, S., and Chen, H. (2006). Structural properties and enzymatic hydrolysis of rice straw. Process Biochem. 41, 1261-1264. doi: 10.1016/j.procbio.2005.12.022

Jin, S., and Chen, H. (2007). Nearinfrared analysis of the chemical composition of rice straw. Ind. Crops Prod. 26, 207-211. doi: 10.1016/j.indcrop.2007.03.004

Jordan, D., Bowman, M., Braker J., Dien, B., Hector, R., Lee, C., et al. (2012). Plant cell walls to ethanol. Biochem. J. 442, 241. doi: 10.1042/BJ20111922

Jung, H.-J. G., Samac, D. A., and Sarath, G. (2012). Modifying crops to increase cell wall digestibility Plant Sci. 185-186, 65-77. doi: 10.1016/j.plantsci.2011.10.014

Kaar, W. E., Gutierrez, C. V., and Kinoshita, C. M. (1998). Steam explosion of sugarcane bagasse as a pretreatment for conversion to ethanol. Biomass Bioenergy 14, 277-287. doi 10.1016/S0961-9534(97)10038-1

Kargbo, F., Xing, J., and Zhang, Y. (2010). Property analysis and pretreatment of rice straw for energy use in grain drying: a review. Agric. Biol. J. N. Am. 1, 195-200.

Keeping, M. G., Kvedaras, O. L., and Bruton, A. G. (2009). Epidermal silicon in sugarcane: cultivar differences and role in resistance to sugarcane borer Eldana saccharina. Environ. Exp. Bot. 66, 54-60. doi: $\quad 10.1016 /$ j.envexpbot.2008. 12.012

Kelly, E. N., Schindler, D. W., Hodson, P. V., Short, J. W., Radmanovich, R., and Nielsen, C. C. (2010). Oil sands development contributes elements toxic at low concentrations to the Athabasca river and its tributaries. Proc. Natl. Acad. Sci.U.S.A. 107, 16178-16183. doi: 10.1073/pnas. 1008754107

Klasnja, B., Kopitovic, S., and Orlovic, S. (2002). Wood and bark of some poplar and willow clones as fuelwood. Biomas Bioenergy 23, 427-432. doi: 10.1016/S0961-9534(02)00069-7

Kumar, R., Pandey, K. K., Chandrashekar, N., and Mohan, S. (2011). Study of age and height wise variability on calorific value and other fuel properties of Eucalyptus hybrid, Acacia auriculaeformis and Casuarina equisetifolia. Biomass Bioenergy 35, 1339-1344. doi: $\quad$ 10.1016/j.biombioe.2010 12.031

Lam, P. S., Sokhansanj, S., Bi, X., Lim, C. J., Naimi, L. J., Hoque, M., et al.
(2008). Bulk density of wet and dry wheat straw and switchgrass particles. Appl. Eng. Agric. 24, 351-358.

Landström, S., Lomakka, L., and Andersson, S. (1996). Harvest in spring improves yield and quality of reed canary grass as a bioenergy crop. Biomass Bioenergy 11, 333-341. doi: 10.1016/0961-9534(96)00041-4

Laurens, L. M. L., and Wolfrum, E. J. (2011). Feasibility of spectroscopic characterization of algal lipids: chemometric correlation of NIR and FTIR spectra with exogenous lipids in algal biomass. Bioenerg. Res. 4, 22-35. doi: 10.1007/s12155-010-9098-y

Lee, S. J., Warnick, T. A., Pattathil, S., Alvelo-Maurosa, J. G., Serapiglia, M. J., McCormick, H., et al. (2012). Biological conversion assay using Clostridium phytofermentans to estimate plant feedstock quality. Biotechnol. Biofuels 5, 5. doi: 10.1186/1754-6834-5-5

Lemus, R., Brummer, E. C., Moore, K. J., Molstad, N. E., Burras, C. L., and Barker, M. F. (2002). Biomass yield and quality of 20 switchgrass populations in southern Iowa, USA. Biomass Bioenergy 23, 433-442. doi: $\quad 10.1016 / S 0961-9534(02)$ 00073-9

Lestander, T. A., Johnsson, B., and Grothage, M. (2009). NIR techniques create added values for the pellet and biofuel industry. Bioresour. Technol. 100, 1589-1594. doi: $\quad$ 10.1016/j.biortech.2008. 08.001

Lestander, T. A., and Rhén, C. (2005). Multivariate NIR spectroscopy models for moisture, ash and calorific content in biofuels using bi-orthogonal partial least squares regression. Analyst 130, 1182-1189. doi: 10.1039/b500103j

Lewandowski, I., and Kicherer, A. (1997). Combustion quality of biomass: practical relevance and experiments to modify the biomass quality of Miscanthus $x$ giganteus. Eur. J. Agron. 6, 163-177. doi: $\quad 10.1016 /$ S1161-0301(96) 02044-8

Li, W., Shao, M., Zhong, W., Yang, J., Okada, K., Yamane, H., et al. (2012). Ectopic expression of Hrfl enhances bacterial resistance via regulation of diterpene phytoalexins, silicon and reactive oxygen species burst in rice. PLOS ONE 7:e43914. doi: 10.1371/journal. pone. 0043914

Lindh, T., Paappanen, T., Rinne, S., Sivonen, K., and Wihersaari, M. (2009). Reed canary grass transportation costs-reducing costs 
and increasing feasible transportation distances. Biomass Bioenergy 33, 209-212. doi: 10.1016/j.biombioe.2008.05.019

Lingle, S. E., and Thomson, J. L. (2011). Sugarcane internode composition during crop development. Bioenerg. Res. 5, 168-178. doi: 10.1007/s12155-011-9153-3

Liu, L., Ye, X. P., Womac, A. R., and Sokhansanj, S. (2010). Variability of biomass chemical composition and rapid analysis using FT-NIR techniques. Carbohydr. Polym. 81, 820-829. doi: 10.1016/j.carbpol.2010.03.058

Liu, Z., Xu, A., and Zhao, T. (2011). Energy from combustion of rice straw: status and challenges to China. Energy Power Eng. 3, 325-331. doi: 10.4236/epe.2011. 33040

Lötjönen, T., and Paappanen, T. (2013). Bale density of reed canary grass spring harvest. Biomass Bioenergy 51, 53-59. doi: 10.1016/j.biombioe.2012.12.041

Lv, D., Xu, M., Liu, X., Zhan, Z., Li, Z., and Yao, H. (2010). Effect of cellulose, lignin, alkali and alkaline earth metallic species on biomass pyrolysis and gasification. Fuel Process. Technol. 91, 903-909. doi: 10.1016/j.fuproc.2009.09.014

Ma, J. F., and Takahashi, E. (eds.). (2002). Soil, Fertilizer, and Plant Silicon Research in Japan. 1st Edn. Amsterdam: Elsevier Science.

Ma, J. F., Yamaji, N., and MitaniUeno, N. (2011). Transport of silicon from roots to panicles in plants. Proc. Jpn. Acad. Ser. B Phys. Biol. Sci. 87, 377-385. doi: 10.2183/pjab. 87.377

Mackay, T. F. (2001). The genetic architecture of quantitative traits. Annu. Rev. Genet. 35, 303-39. doi: 10.1146/annurev.genet.35.102401. 090633

Mani, S., Tabil, L. G., and Sokhansanj, S. (2004). Grinding performance and physical properties of wheat and barley straws, corn stover and switchgrass. Biomass Bioenergy 27, 339-352. doi: 10.1016/j.biombioe. 2004.03.007

Mann, D. G. J., Labbé, N., Sykes, R. W., Gracom, K., Kline, L., Swamidoss, I. M., et al. (2009). Rapid assessment of lignin content and structure in switchgrass (Panicum virgatum L.) grown under different environmental conditions. Bioenerg. Res. 2, 246-256.

Mansaray, K. G., Ghaly, A. E., AlTaweel, A. M., Hamdullahpur, F., and Ugursal, V. I. (1999). Air gasification of rice husk in a dual distributor type fluidized bed gasifier.
Biomass Bioenergy 17, 315-332. doi: 10.1016/S0961-9534(99)00046-X

Mäser, P., Thomine, S., Schroeder, J. I., Ward, J. M., Hirschi, K., Sze, H., et al. (2001). Phylogenetic relationships within cation transporter families of Arabidopsis. Plant Physiol. 126, 1646-1667. doi: 10.1104/pp.126.4.1646

McCann, S. E., and Huang, B. (2008). Evaluation of drought tolerance and avoidance traits for six creeping bentgrass cultivars. Hortscience 43 , 519-524.

McKendry, P. (2002a). Energy production from biomass (part 1): overview of biomass. Bioresour. Technol. 83, 37-46.

McKendry, P. (2002b). Energy production from biomass (part 2): conversion technologies. Bioresour. Technol. 83, 47-54.

McKendry, P. (2002c). Energy production from biomass (part 3): gasification technologies. Bioresour. Technol. 83, 55-63.

Miao, Z., Grift, T. E., Hansen, A. C., and Ting, K. C. (2011). Energy requirement for comminution of biomass in relation to particle physical properties. Ind. Crops Prod. 33, 504-513. doi: 10.1016/j.indcrop. 2010.12.016

Miles, T. R., Miles Jr, T. R., Baxter, L. L., Bryers, R. W., Jenkins, B. M., and Oden, L. L. (1996). Boiler deposits from firing biomass fuels. Biomass Bioenergy 10, 125-138. doi: 10.1016/0961-9534(95)00067-4

Milne, T. A., Abatzoglou, N., and Evans, R. J. (1998). Biomass Gasifier "Tars": Their Nature, Formation, and Conversion. Golden, CO: National Renewable Energy Laboratory. doi: $10.2172 / 3726$

Mitani, N., Ma, J. F., and Iwashita, T. (2005). Identification of the silicon form in xylem sap of rice (Oryza sativa L.). Plant Cell physiol. 46, 279-283. doi: 10.1093/pcp/pci018

Molinari, H. B., Pellny, T. K., Freeman, J., Shewry, P. R., and Mitchell, R. A. (2013). Grass cell wall feruloylation: distribution of bound ferulate and candidate gene expression in Brachypodium distachyon. Front. Plant Sci. 4:50. doi: 10.3389/fpls.2013.00050

Monono, E. M., Nyren, P. E., Berti, M. T., and Pryor, S. W. (2013). Variability in biomass yield, chemical composition, and ethanol potential of individual and mixed herbaceous biomass species grown in North Dakota. Ind. Crops Prod. 41, 331-339. doi: 10.1016/j.indcrop.2012.04.051

Montes, J. M., Technow, F., Dhillon, B. S., Mauch, F., and Melchinger,
A. E. (2011). High-throughput nondestructive biomass determination during early plant development in maize under field conditions. Field Crops Res. 121, 268-273. doi 10.1016/j.fcr.2010.12.017

Monti, A., Di Virgilio, N., and Venturi, G. (2008). Mineral composition and ash content of six major energy crops. Biomass Bioenergy 32, 216-223. doi: 10.1016/j.biombioe.2007.09.012

Mosse, J. (1990). Nitrogen-to-protein conversion factor for ten cereals and six legumes or oilseeds. A reappraisal of its definition and determination. Variation according to species and to seed protein content. J. Agric. Food Chem. 38, 18-24. doi: 10.1021/jf00091a004

Mosseler, A., Zsuffa, L., Stoehr, M. U., and Kenney, W. A. (1988). Variation in biomass production, moisture content, and specific gravity in some North American willows (Salix, L.) Can. J. For. Res. 18, 1535-1540. doi: $10.1139 / x 88-235$

Moxley, G., and Zhang, Y.-H. P. (2007). More accurate determination of acid-labile carbohydrates in lignocellulose by modified quantitative saccharification. Energy Fuels 21, 3684-3688. doi: 10.1021/ ef7003893

Müller-Hagedorn, M., Bockhorn, H., Krebs, L., and Müller, U. (2003). A comparative kinetic study on the pyrolysis of three different wood species. J. Anal. Appl. Pyrolysis 68 69, 231-249. doi: 10.1016/S01652370(03)00065-2

Nassi o Di Nasso, N., Angelini, L. G., and Bonari, E. (2010). Influence of fertilisation and harvest time on fuel quality of giant reed (Arundo donax L.) in central Italy. Eur. J. Agron. 32, 219-227. doi: 10.1016/j.eja.2009.12.001

National Research Council. (2011). Renewable Fuel Standard: Potential Economic and Environmental Effects of U.S. Biofuel Policy. Washington, DC: The National Academies Press.

Nishimura, K., Miyake, Y., and Takahashi, E. (1989). On silicon, aluminium, and zinc accumulators discriminated from 147 species of Angiospermae. Mem. Coll. Agric. Kyoto Univ. 133, 23-43.

Noble, J. E., and Bailey, M. J. A. (2009). "Chapter 8 quantitation of protein," in Methods in Enzymology, (San Diego, CA: Elsevier), 73-95.

Nookaraju, A., Pandey, S. K., Bae, H.J., and Joshi, C. P. (2013). Designing cell walls for improved bioenergy production. Mol. Plant 6, 8-10.

Normanly, J. (Ed.). (2012). HighThroughput Phenotyping in Plants.
New York,NY: Humana Press. doi: 10.1007/978-1-61779-995-2

Oak Ridge National Laboratory. (2008). Appendix B-Biomass Characteristics. Biomass Energy Data Book. Available online at: http://cta.ornl. gov/bedb/appendix_b.shtml (Accessed December 15, 2012).

Osborn, S. G., Vengosh, A., Warner, N. R., and Jackson, R. B. (2011). Methane contamination of drinking water accompanying gas-well drilling and hydraulic fracturing. Proc. Natl. Acad. Sci. U.S.A. 108, 8172-8176. doi: 10.1073/pnas.1100682108

Patakas, A., Nikolaou, N., Zioziou, E., Radoglou, K., and Noitsakis, B. (2002). The role of organic solute and ion accumulation in osmotic adjustment in drought-stressed grapevines. Plant Sci. 163, 361-367. doi: $\quad 10.1016 / S 0168-9452(02)$ 00140-1

Pattathil, S., Avci, U., Miller, J. S., and Hahn, M. G. (2012). "Immunological approaches to plant cell wall and biomass characterization: glycome profiling," in Biomass Conversion, ed M. E. Himmel (Totowa, NJ: Humana Press), 61-72.

Pauly, M., and Keegstra, K. (2008). Cell-wall carbohydrates and their modification as a resource for biofuels. Plant J. 54, 559-568. doi: 10.1111/j.1365-313X.2008.03463.x

Penning, B. W., Hunter, C. T., Tayengwa, R., Eveland, A. L., Dugard, C. K., Olek, A. T., et al. (2009). Genetic resources for maize cell wall biology. Plant Physiol. 151, 1703-1728. doi: 10.1104/pp.109.136804

Pereira, E. G., da Silva, J. N., de Oliveira, J. L., and Machado, C. S. (2012). Sustainable energy: a review of gasification technologies. Renew. Sustain. Energy Rev. 16, 4753-4762. doi: 10.1016/j.rser. 2012.04.023

Peterson, A. A., Vogel, F., Lachance, R. P., Fröling, M., Michael, J., Antal, J., et al. (2008). Thermochemical biofuel production in hydrothermal media: a review of sub- and supercritical water technologies. Energy Environ. Sci. 1, 32-65.

Petrolia, D. R. (2008). The economics of harvesting and transporting corn stover for conversion to fuel ethanol: a case study for Minnesota. Biomass Bioenergy 32, 603-612. doi: 10.1016/j.biombioe.2007. 12.012

Prychid, C. J., Rudall, P. J., and Gregory, M. (2003). Systematics and biology of silica bodies in monocotyledons. Bot. Rev. 69 
377-440. doi: 10.1663/0006-8101 (2004)069[0377:SABOSB]2.0.CO;2

Raboy, V. (2003). myo-Inositol-1 2, 3 4, 5, 6-hexakisphosphate. Phytochemistry 64, 1033-1043. doi: 10.1016/S0031-9422(03)00446-1

Rancour, D. M., Marita, J. M., and Hatfield, R. D. (2012). Cell wall composition throughout development for the model grass Brachypodium distachyon. Front. Plant Sci. 3:266. doi: 10.3389/fpls.2012.00266

Raveendran, K., Ganesh, A., and Khilar, K. C. (1995). Influence of mineral matter on biomass pyrolysis characteristics. Fuel 74, 1812-1822. doi: 10.1016/0016-2361(95)80013-8

Raven, J. A. (1983). The transport and function of silicon in plants. Biol. Rev. 58, 179-207. doi: $\quad 10.1111 / \mathrm{j} .1469-185 X .1983 . t b$ 00385.x

Reich, G. (2005). Near-infrared spectroscopy and imaging: basic principles and pharmaceutical applications. Adv. Drug Deliv. Rev. 57, 1109-1143. doi: 10.1016/j.addr.2005.01.020

Richmond, K. E., and Sussman, M. (2003). Got silicon. The non-essential beneficial plant nutrient. Curr. Opin. Plant Biol. 6, 268-272. doi: 10.1016/S1369-5266 (03)00041-4

Riley, J. T. (2007). Manual 57 Routine Coal and Coke Analysis: Collection, Interpretation, and Use of Analytical Data. West Conshohocken, PA: ASTM International.

Robbins, M. P., Evans, G., Valentine, J., Donnison, I. S., and Allison, G. G. (2012). New opportunities for the exploitation of energy crops by thermochemical conversion in Northern Europe and the UK. Prog. Energy.Combust. Sci. 38, 138-155. doi: 10.1016/j.pecs.2011.08.001

Roberts, C. A., Houx, J. H., and Fritschi, F. B. (2011). Near-Infrared analysis of sweet Sorghum Bagasse. Crop Sci. 51, 2284. doi: $10.2135 /$ cropsci2010.12.0691

Sabatier, D., Thuriès, L., Bastianelli, D., and Dardenne, P. (2012). Rapid prediction of the lignocellulosic compounds of sugarcane biomass by near infrared reflectance spectroscopy: comparing classical and independent cross-validation. J. Near Infrared Spectrosc. 20, 371. doi: 10.1255/jnirs.999

Saito, K., Yamamoto, A., Sa, T., and Saigusa, M. (2005). Rapid, micro-methods to estimate plant silicon content by dilute hydrofluoric acid extraction and spectrometric molybdenum method. Soil Sci. Plant Nutr.
51, 29-36. doi: 10.1111/j.17470765.2005.tb00003.x

Salt, D. E., Baxter, I., and Lahner, B. (2008). Ionomics and the study of the plant ionome. Annu. Rev. Plant Biol. 59, 709-733. doi: 10.1146/annurev.arplant.59.032607. 092942

Sanderson, M. A., Agblevor, F., Collins, M., and Johnson, D. K. (1996). Compositional analysis of biomass feedstocks by near infrared reflectance spectroscopy. Biomass Bioenergy 11, 365-370. doi: 10.1016/S0961-9534(96)00039-6

Santoro, N., Cantu, S. L., Tornqvist, C.-E., Falbel, T. G., Bolivar, J. L., Patterson, S. E., et al. (2010). A high-throughput platform for screening milligram quantities of plant biomass for lignocellulose digestibility. Bioenerg. Res. 3, 93-102. doi: 10.1007/s12155-009-9074-6

Sapan, C. V., Lundblad, R. L., and Price, N. C. (1999). Colorimetric protein assay techniques. Biotechnol. Appl. Biochem. 29, 99-108.

Searcy, E., and Flynn, P. C. (2010). A criterion for selecting renewable energy processes. Biomass Bioenergy 34, 798-804. doi: 10.1016/j.biombioe.2010.01.023

Seelig, H. D., Hoehn, A., Stodieck, L. S., Klaus, D. M., Adams, W. W. III., and Emery, W. J. (2008). The assessment of leaf water content using leaf reflectance ratios in the visible, near-, and short wave infrared. Int. J. Remote Sens. 29, 3701-3713. doi: 10.1080/014311 60701772500

Serapiglia, M. J., Cameron, K. D., Stipanovic, A. J., Abrahamson, L. P. Volk, T. A., and Smart, L. B. (2013). Yield and woody biomass traits of novel shrub willow hybrids at two contrasting sites. Bioenerg. Res. 6, 533-546. doi: 10.1007/s12155-0129272-5

Serapiglia, M. J., Cameron, K. D., Stipanovic, A. J., and Smart, L. B. (2009). Analysis of biomass composition using high-resolution thermogravimetric analysis and percent bark content for the selection of shrub willow bioenergy crop varieties. Bioenerg. Res. 2, 1-9. doi: 10.1007/s12155-008-9028-4

Shackley, S., Carter, S., Knowles, T., Middelink, E., Haefele, S., and Haszeldine, S. (2012). Sustainable gasification-biochar systems. A case-study of rice-husk gasification in Cambodia, part II: field trial results, carbon abatement, economic assessment and conclusions. Energy Policy 41, 618-623. doi: 10.1016/j.enpol.2011.11.023
Shen, D. K., Gu, S., Luo, K. H. Wang, S. R., and Fang, M. X. (2010). The pyrolytic degradation of wood-derived lignin from pulping process. Bioresour. Technol. 101, 6136-6146. doi: 10.1016/j.biortech 2010.02.078

Shen, H., Fu, C., Xiao, X., Ray, T., Tang, Y., Wang, Z., et al. (2009). Developmental control of lignification in stems of lowland switchgrass variety alamo and the effects on saccharification efficiency. Bioenerg. Res. 2, 233-245. doi: 10.1007/s12155-009-9058-6

Sheng, C., and Azevedo, J. L. T. (2005). Estimating the higher heating value of biomass fuels from basic analysis data. Biomass Bioenergy 28, 499-507. doi: 10.1016/j.biombioe.2004.11.008

Singh, M. P., Erickson, J. E. Sollenberger, L. E., Woodard, K. R., Vendramini, J. M. B., and Fedenko, J. R. (2012). Mineral composition and biomass partitioning of sweet sorghum grown for bioenergy in the southeastern USA. Biomass Bioenergy 47, 1-8. doi: 10.1016/j.biombioe.2012.10.022

Sluiter, J. B., Ruiz, R. O., Scarlata, C. J., Sluiter, A. D., and Templeton, D. W. (2010). Compositional analysis of lignocellulosic feedstocks. 1. Review and description of methods. J. Agric. Food Chem. 58, 9043-9053. doi: 10.1021/jf1008023

Smets, K., Adriaensens, P., Reggers, G., Schreurs, S., Carleer, R., and Yperman, J. (2011). Flash pyrolysis of rapeseed cake: influence of temperature on the yield and the characteristics of the pyrolysis liq uid. J. Anal. Appl. Pyrolysis 90, 118-125. doi: 10.1016/j.jaap.2010. 11.002

Smith, R. D., Peart, R. M., Liljedahl, J. B., Barrett, J. R., and Doering, O. C. (1985). Corncob property changes during outside storage. Trans. Am Soc. Agric. Biol. Eng. 28, 937-942.

Sokhansanj, S., Bi, X., Naimi, L. Hoque, M., Mani, S., and Narayan, S. (2008). Bulk density of wet and dry wheat straw and switchgrass particles. Appl. Eng. Agric. 24, 351-358.

Sokhansanj, S., Mani, S., Turhollow, A., Kumar, A., Bransby, D., Lynd, L., et al. (2009). Large-scale production, harvest and logistics of switchgrass (Panicum virgatum L.) - current technology and envisioning a mature technology. Biofuels Bioprod. Bioref. 3, 124-141. doi: 10.1002/bbb. 129

Solantausta, Y., Oasmaa, A., Sipilä, K., Lindfors, C., Lehto, J., Autio, J., et al. (2012). Bio-oil production from biomass: steps toward demonstration. Energy Fuels 26, 233-240. doi: 10.1021/ef201109t

Sommer, M., Kaczorek, D., Kuzyakov, Y., and Breuer, J. (2006). Silicon pools and fluxes in soils and landscapes-a review. J. Plant Nutr. Soil Sci. 169, 310-329. doi: 10.1002/jpln.200521981

Spinelli, R., Nati, C., and Magagnotti, N. (2009). Using modified foragers to harvest short-rotation poplar plantations. Biomass Bioenergy 33, 817-821. doi: 10.1016/j.biombioe.2009.01.001

Spokas, K. A. (2010). Review of the stability of biochar in soils: predictability of O:C molar ratios. Carbon Manage. 1, 289-303. doi: $10.4155 / \mathrm{cmt} .10 .32$

Studer, M. H., DeMartini, J. D., Davis, M. F., Sykes, R. W., Davison, B., Keller, M., et al. (2011). Lignin content in natural populus variants affects sugar release. Proc. Natl. Acad. Sci.U.S.A. 108, 6300-6305. doi: 10.1073/pnas.1009252108

Summers, M., Jenkins, B., Hyde, P., Williams, J., Mutters, R., Scardacci, S., et al. (2003). Biomass production and allocation in rice with implications for straw harvesting and utilization. Biomass Bioenergy 24, 163-173. doi: 10.1016/S09619534(02)00132-0

Suzuki, S., Suzuki, Y., Yamamoto, N., Hattori, T., Sakamoto, M., and Umezawa, T. (2009). Highthroughput determination of thioglycolic acid lignin from rice. Plant Biotechnol. 26, 337-340. doi: 10.5511/plantbiotechnology.26.337

Taiz, L., and Zeiger, E. (2006). Plant physiology. 4th Edn. Sunderland, MA: Sinauer Associates.

Takeda, S., and Matsuoka, M. (2008). Genetic approaches to crop improvement: responding to environmental and population changes. Nat. Rev. Genet. 9, 444-457. doi: $10.1038 / \operatorname{nrg} 2342$

Tao, G., Geladi, P., Lestander, T. A., and Xiong, S. (2012a). Biomass properties in association with plant species and assortments. II: a synthesis based on literature data for ash elements. Renew. Sustain. Energy Rev. 16, 3507-3522. doi: 10.1016/j.rser.2012.01.023

Tao, G., Lestander, T. A., Geladi, P., and Xiong, S. (2012b). Biomass properties in association with plant species and assortments I: a synthesis based on literature data of energy properties. Renew. Sustain. Energy Rev. 16, 3481-3506. doi: 10.1016/j.rser.2012.02.039

Theander, O., Aman, P., Westerlund, E., Andersson, R., and Petersson, 
D. (1995). Total dietary fiber determined as neutral sugar residues, uronic acid residues, and klason lignin (The Uppsala method): collaborative study. J. AOAC Int. 78, 1030-1044.

Tröger, N., Richter, D., and Stahl, R. (2013). Effect of feedstock composition on product yields and energy recovery rates of fast pyrolysis products from different straw types. J. Anal. Appl. Pyrolysis 100, 158-165. doi: 10.1016/j.jaap.2012.12.012

Tsai, W. T., Lee, M. K., and Chang, Y. M. (2006). Fast pyrolysis of rice straw, sugarcane bagasse and coconut shell in an induction-heating reactor. J. Anal. Appl. Pyrolysis 76, 230-237. doi: 10.1016/j.jaap.2005.11.007

Uden, P., Robinson, P., and Wiseman, J. (2005). Use of detergent system terminology and criteria for submission of manuscripts on new, or revised, analytical methods as well as descriptive information on feed analysis and/or variability. Anim. Feed Sci. Technol. 118, 181-186. doi: 10.1016/j.anifeedsci. 2004.11.011

USDA. (2010). A USDA Regional Roadmap to Meeting the Biofuels Goals of the Renewable Fuels Standard by 2022. Available at: http://www.usda.gov/documents/US DA_Biofuels_Report_6232010.pdf.

Van der Stelt, M. J. C., Gerhauser, H., Kiel, J. H. A., and Ptasinski, K. J. (2011). Biomass upgrading by torrefaction for the production of biofuels: a review. Biomass Bioenergy. 35, 3748-3762. doi: 10.1016/j.biombioe.2011.06.023

Van Loo, S., and Koppejan, J. (2008). The Handbook of Biomass Combustion and Co-firing. Sterling, VA: Earthscan/James and James.

Van Soest, P. J., Robertson, J. B., and Lewis, B. A. (1991). Methods for dietary fiber, neutral detergent fiber, and nonstarch polysaccharides in relation to animal nutrition. J. Dairy Sci. 74, 3583-3597. doi: 10.3168/jds.S00220302(91)78551-2

Vassilev, S. V., Baxter, D., Andersen, L. K., and Vassileva, C. G. (2010). An overview of the chemical composition of biomass. Fuel 89, 913-933. doi: 10.1016/j.fuel.2009.10.022

Vermerris, W. (2011). Survey of genomics approaches to improve bioenergy traits in maize, sorghum and sugarcanefree access. J. Integr. Plant Biol. 53, 105-119. doi: 10.1111/j.1744-7909.2010.01020.x

Vermerris, W., and Saballos, A. (2013). "Genetic enhancement of sorghum for biomass utilization," in Genomics of the Saccharinae Plant
Genetics and Genomics: Crops and Models, ed A. H. Paterson (New York, NY: Springer), 391-425.

Voelker, S. L., Lachenbruch, B., Meinzer, F. C., Jourdes, M., Ki, C., Patten, A. M., et al. (2010) Antisense down-regulation of 4CL expression alters lignification, tree growth, and saccharification potential of field-grown poplar. Plant Physiol. 154, 874-886. doi: 10.1104/pp.110.159269

Vogel, K. P., Dien, B. S., Jung, H. G., Casler, M. D., Masterson, S. D., and Mitchell, R. B. (2010). Quantifying actual and theoretical ethanol yields for switchgrass strains using NIRS analyses. Bioenerg. Res. 4 96-110. doi: 10.1007/s12155-0109104-4

Vogel, K. P., Pedersen, J. F., Masterson, S. D., and Toy, J. J. (1999). Evaluation of a filter bag system for NDF, ADF, and IVDMD forage analysis. Crop Sci. 39, 276-279. doi: 10.2135/cropsci1999.0011183X003900010042x

Waldner, M. H., and Vogel, F. (2005). Renewable production of methane from woody biomass by catalytic hydrothermal gasification. Ind. Eng. Chem. Res. 44, 4543-4551. doi 10.1021/ie050161h

Wang, H., Avci, U., Nakashima, J., Hahn, M. G., Chen, F., and Dixon, R. A. (2010). Mutation of WRKY transcription factors initiates pith secondary wall formation and increases stem biomass in dicotyledonous plants. Proc. Natl. Acad. Sci.U.S.A. 107, 22338-22343. doi 10.1073/pnas.1016436107

Wang, H.-Z., and Dixon, R. A. (2012). On-Off switches for secondary cell wall biosynthesis. Mol. Plant 5, 297-303. doi: 10.1093/mp/ssr098

Wang, L., Weller, C. L., Jones, D. D., and Hanna, M. A. (2008). Contemporary issues in thermal gasification of biomass and its application to electricity and fuel production. Biomass Bioenergy 32, 573-581. doi: 10.1016/j.biombioe.2007.12.007

Wang, M. Q., Han, J., Haq, Z., Tyner, W. E., Wu, M., and Elgowainy, A. (2011). Energy and greenhouse gas emission effects of corn and cellulosic ethanol with technology improvements and land use changes. Biomass Bioenergy 35, 1885-1896. doi: $\quad 10.1016 /$ j.biombioe.2011 01.028

Weng, J.-K., Li, X., Bonawitz, N. D., and Chapple, C. (2008). Emerging strategies of lignin engineering and degradation for cellulosic biofuel production. Curr. Opin.
Biotechnol. 19, 166-172. doi: 10.1016/j.copbio.2008.02.014

Werkelin, J., Skrifvars, B.-J., and Hupa, M. (2005). Ash-forming elements in four Scandinavian wood species. Part 1: summer harvest. Biomass Bioenergy 29, 451-466. doi: 10.1016/j.biombioe.2005.06.005

White, J. W., Andrade-Sanchez, P., Gore, M. A., Bronson, K. F., Coffelt, T. A., Conley, M. M., et al. (2012). Field-based phenomics for plant genetics research. Field Crops Res. 133, 101-112. doi 10.1016/j.fcr.2012.04.003

Williams, A., Jones, J. M., Ma, L., and Pourkashanian, M. (2012). Pollutants from the combustion of solid biomass fuels. Prog. Energy Combust. Sci. 38, 113-137. doi: 10.1016/j.pecs.2011.10.001

Wilson, D. M., Dalluge, D. L., Rover, M., Heaton, E. A., and Brown, R. C. (2013). Crop management impacts biofuel quality: influence of switchgrass harvest time on yield, nitrogen and ash of fast pyrolysis products. Bioenerg. Res. 6, 103-113. doi: 10.1007/s12155-012-9240-0

Winslow, M. D., Okada, K., and Correa-Victoria, F. (1997). Silicon deficiency and the adaptation of tropical rice ecotypes Plant Soil 188, 239-248. doi 10.1023/A:1004298817861

Wolfrum, E., Lorenz, A., and deLeon, N. (2009). Correlating detergent fiber analysis and dietary fiber analysis data for corn stover collected by NIRS. Cellulose 16, 577-585. doi 10.1007/s10570-009-9318-9

Wolfrum, E., and Sluiter, A. (2009). Improved multivariate calibration models for corn stover feedstock and dilute-acid pretreated corn stover. Cellulose 16 567-576. doi: 10.1007/s10570-0099320-2

Wright, M. M., and Brown, R. C. (2007). Comparative economics of biorefineries based on the biochemical and thermochemical platforms. Biofuels Bioprod. Bioref. 1, 49-56. doi: 10.1002/bbb. 8

Wu, Q. S., Wan, X. Y., Su, N., Cheng, Z. J., Wang, J. K., Lei, C. L., et al. (2006). Genetic dissection of silicon uptake ability in rice (Oryza sativa L.). Plant Sci. 171, 441-448. doi 10.1016/j.plantsci.2006.05.001

Wu, Y., Wu, S., Li, Y., and Gao, J. (2009). Physico-chemical characteristics and mineral transformation behavior of ashes from crop straw. Energy Fuels 23, 5144-5150. doi: $10.1021 / \mathrm{ef} 900496 \mathrm{~b}$

Xu, Z., Zhang, D., Hu, J., Zhou, X. Ye, X., Reichel, K., et al. (2009). Comparative genome analysis of lignin biosynthesis gene families across the plant kingdom. BMC Bioinformatics 10:S3. doi: 10.1186/1471-2105-10-S11-S3

Yang, F., Mitra, P., Zhang, L., Prak, L., Verhertbruggen, Y., Kim, J.-S., et al. (2012). Engineering secondary cell wall deposition in plants. Plant Biotechnol. J. 11, 325-335. doi: 10.1111/pbi.12016

Yin, C., Rosendahl, L. A., and Kær, S. K. (2008). Grate-firing of biomass for heat and power production. Prog. Energy Combust. Sci. 34, 725-754. doi: 10.1016/j.pecs.2008.05.002

Yin, X. L., Wu, C. Z., Zheng, S. P., and Chen, Y. (2002). Design and operation of a CFB gasification and power generation system for rice husk. Biomass Bioenergy 23 , 181-187. doi: 10.1016/S0961-9534 (02)00042-9

Yoshida, S., Ohnishi, Y., and Kitagishi, K. (1962). Chemical forms, mobility and deposition of silicon in rice plant. Soil Sci. Plant Nutr. 8, 15-21. doi: 10.1080/00380768.1962.10430992

Yoshida, T., Oshima, Y., and Matsumura, Y. (2004). Gasification of biomass model compounds and real biomass in supercritical water Biomass Bioenergy 26, 71-78. doi: 10.1016/S0961-9534(03)00063-1

Zhang, C., Wang, L., Zhang, W., and Zhang, F. (2013). Do lignification and silicification of the cell wall precede silicon deposition in the silica cell of the rice (Oryza sativa L.) leaf epidermis. Plant Soil. doi: 10.1007/ s11104-013-1723-z. [Epub ahead of print]

Zhang, Y., Ghaly, A., and Li, B. (2012). Physical properties of rice residues as affected by variety and climatic and cultivation conditions in three continents. Am. J. Appl. Sci. 9, 1757-1768. doi 10.3844/ajassp.2012.1757.1768

Zhao, Q., and Dixon, R. A. (2011). Transcriptional networks for lignin biosynthesis: more complex than we thought. Trends Plant Sci. 16, 227-233. doi: 10.1016/j.tplants.2010.12.005

Zhao, X., Zhang, L., and Liu, D. (2012a). Biomass recalcitrance. Part I: the chemical compositions and physical structures affecting the enzymatic hydrolysis of lignocellulose. Biofuels Bioprod. Bioref. 6, 465-482. doi: 10.1002/bbb.1331

Zhao, Y. L., Steinberger, Y., Shi, M., Han, L. P., and Xie, G. H. (2012b). Changes in stem composition and harvested produce of sweet sorghum during the period from maturity to a sequence of delayed harvest dates. 
Biomass Bioenergy 39, 261-273. doi: 10.1016/j.biombioe.2012.01.020

Zhou, G., Taylor, G., and Polle, A. (2011). FTIR-ATR-based prediction and modelling of lignin and energy contents reveals independent intra-specific variation of these traits in bioenergy poplars. Plant Methods 7, 9. doi: 10.1186/17464811-7-9

Zhu, C., Gore, M., Buckler, E. S., and Yu, J. (2008). Status and prospects of association mapping in plants. Plant Genome 1, 5-20. doi: 10.3835/plantgenome2008.02.0089

Zhu, J.-K. (2002). Salt and drought stress signal transduction in plants. Annu. Rev. Plant Biol. 53, 247-273. doi: 10.1146/annurev.arplant.53.091401. 143329

Conflict of Interest Statement: The authors declare that the research was conducted in the absence of any commercial or financial relationships that could be construed as a potential conflict of interest.

Received: 29 January 2013; accepted: 05 June 2013; published online: 01 July 2013.

Citation: Tanger P, Field JL, Jahn CE DeFoort MW and Leach JE (2013) Biomass for thermochemical conversion: targets and challenges. Front. Plant Sci. 4:218. doi: 10.3389/fpls.2013.00218
This article was submitted to Frontiers in Plant Biotechnology, a specialty of Frontiers in Plant Science.

Copyright (C) 2013 Tanger, Field, Jahn, DeFoort and Leach. This is an openaccess article distributed under the terms of the Creative Commons Attribution License, which permits use, distribution and reproduction in other forums, provided the original authors and source are credited and subject to any copyright notices concerning any third-party graphics etc. 